In cooperation with the Metropolitan Water Reclamation District of Greater Chicago

\title{
Ground-Water Quality in the Vicinity of Coal-Refuse Areas Reclaimed with Biosolids in Fulton County, Illinois
}

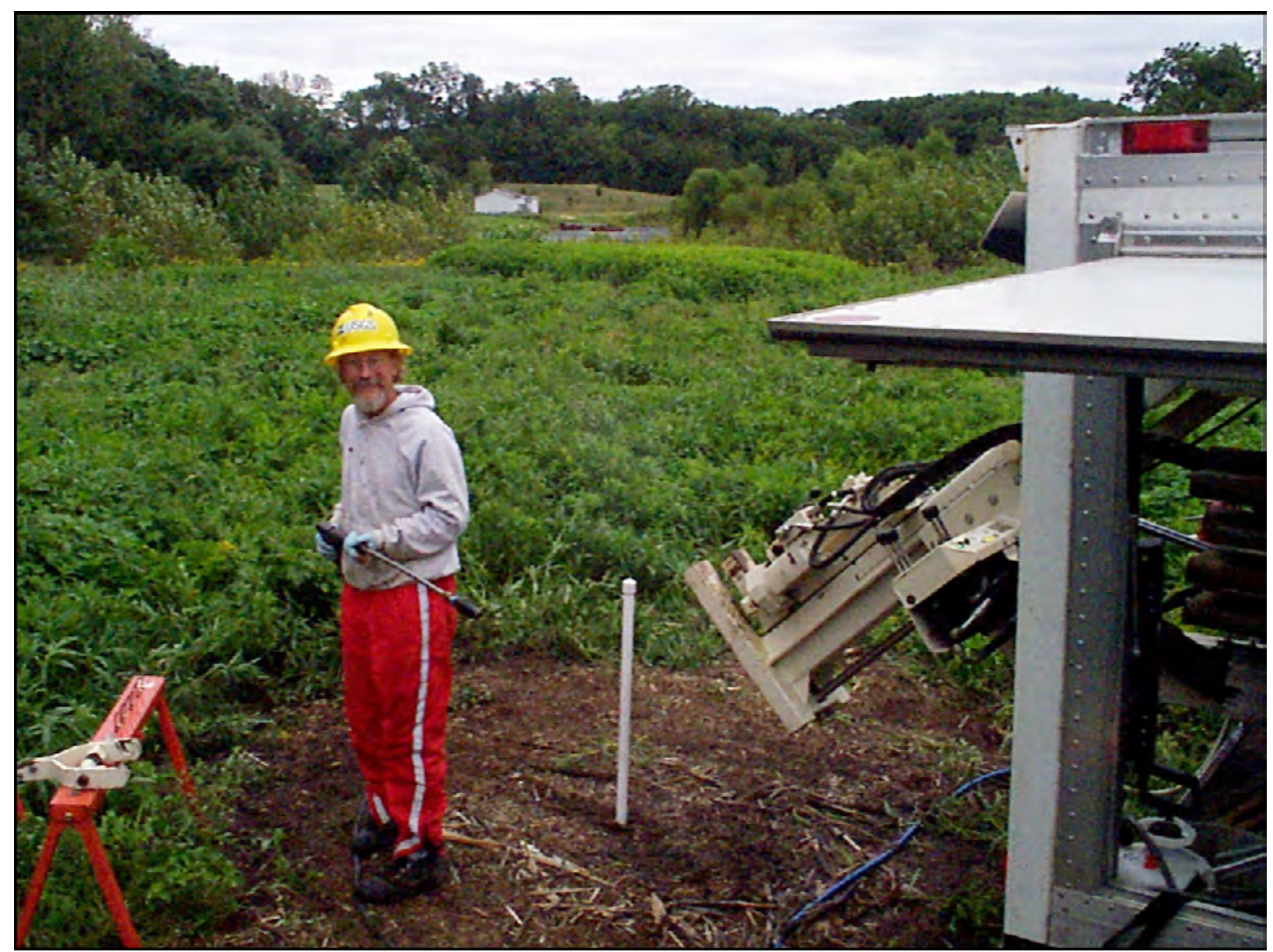

Scientific Investigations Report 2007-5184 
Cover. Photograph of Patrick Mills, U.S. Geological Survey hydrologist, on site near Acid Lake, Fulton County, Illinois. 


\section{Ground-Water Quality in the Vicinity of Coal-Refuse Areas Reclaimed with Biosolids in Fulton County, Illinois}

By William S. Morrow

In cooperation with the Metropolitan Water Reclamation District of Greater Chicago

Scientific Investigations Report 2007-5184 


\section{U.S. Department of the Interior DIRK KEMPTHORNE, Secretary}

\section{U.S. Geological Survey \\ Mark D. Myers, Director}

\section{U.S. Geological Survey, Reston, Virginia: 2007}

For product and ordering information:

World Wide Web: http://www.usgs.gov/pubprod

Telephone: 1-888-ASK-USGS

For more information on the USGS--the Federal source for science about the Earth, its natural and living resources, natural hazards, and the environment:

World Wide Web: http://www.usgs.gov

Telephone: 1-888-ASK-USGS

Any use of trade, product, or firm names is for descriptive purposes only and does not imply endorsement by the U.S. Government.

Although this report is in the public domain, permission must be secured from the individual copyright owners to reproduce any copyrighted materials contained within this report.

Suggested citation:

Morrow, W.S., 2007, Ground-water quality in the vicinity of coal-refuse areas reclaimed with biosolids in Fulton County, Illinois: U.S. Geological Survey Scientific Investigations Report 2007-5184, 42 p. with appendixes. 


\section{Contents}

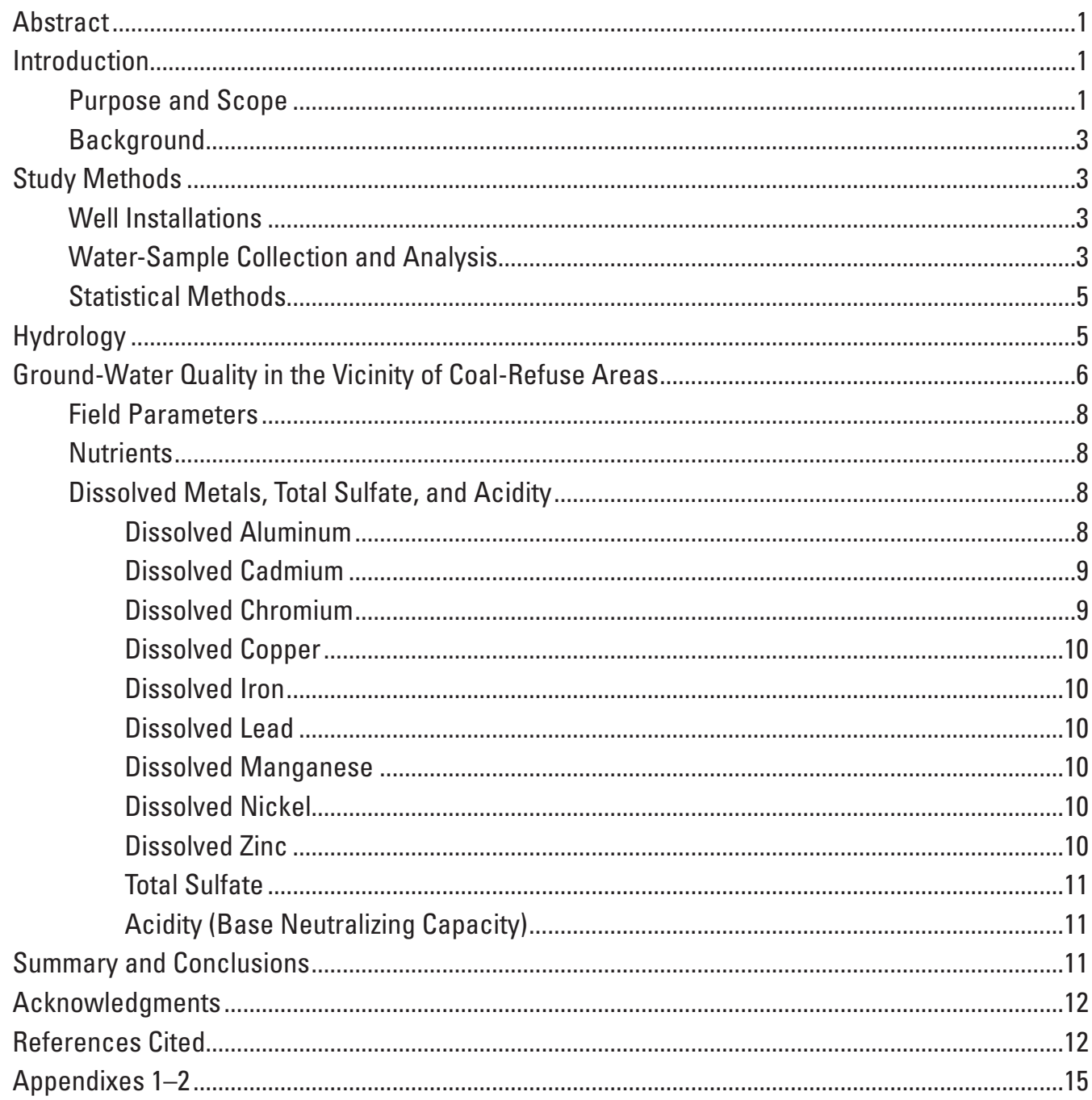

\section{Figures}

\section{1-2. Maps showing-}

1. Location of the Metropolitan Water Reclamation District of Greater Chicago property in Fulton County, Illinois...............................................................................

2. Location of coal-refuse areas in Fulton County, Illinois...........................................

3-4. Graphs showing-

3. Ammonia concentration as a function of the concentration of $(A)$ iron and $(B)$ acidity from wells near coal-refuse areas.

4. Sulfate concentration as a function of the concentration of $(A)$ specific conductivity and $(B)$ acidity from wells near coal-refuse area 


\section{Tables}

1. Field measurements, lab $\mathrm{pH}$, and construction characteristics for shallow ground-water wells in coal-refuse areas in Fulton County, Illinois, fall 2006

2. Acidity, sulfate, and nutrient concentrations for shallow ground-water wells in coal-refuse areas in Fulton County, Illinois, fall 2006.

3. Dissolved metals concentrations for shallow ground-water wells in coal-refuse areas in Fulton County, Illinois, fall 2006.

\section{Appendixes}

1. Geologic Boring and Construction Logs

.16

2. Constituent Concentration Data in Background Wells from 1999-2006

\section{Conversion Factors}

\begin{tabular}{|c|c|c|}
\hline Multiply & By & To obtain \\
\hline \multicolumn{3}{|c|}{ Length } \\
\hline inch (in.) & 2.54 & centimeter $(\mathrm{cm})$ \\
\hline inch (in.) & 25.4 & millimeter $(\mathrm{mm})$ \\
\hline foot $(\mathrm{ft})$ & 0.3048 & meter $(\mathrm{m})$ \\
\hline mile (mi) & 1.609 & kilometer $(\mathrm{km})$ \\
\hline \multicolumn{3}{|c|}{ Area } \\
\hline acre & 4,047 & square meter $\left(\mathrm{m}^{2}\right)$ \\
\hline acre & 0.4047 & hectare (ha) \\
\hline acre & 0.4047 & square hectometer $\left(\mathrm{hm}^{2}\right)$ \\
\hline acre & 0.004047 & square kilometer $\left(\mathrm{km}^{2}\right)$ \\
\hline \multicolumn{3}{|c|}{ Application rate } \\
\hline tons per acre & 2.25 & kilograms per hectare \\
\hline cubic yard per acre & 1.89 & cubic meter $\left(\mathrm{m}^{3}\right)$ per hectare (ha) \\
\hline
\end{tabular}

Temperature in degrees Celsius $\left({ }^{\circ} \mathrm{C}\right)$ may be converted to degrees Fahrenheit $\left({ }^{\circ} \mathrm{F}\right)$ as follows:

$$
{ }^{\circ} \mathrm{F}=\left(1 / 8 \times{ }^{\circ} \mathrm{C}\right)+32
$$

Specific conductance is given in microsiemens per centimeter at 25 degrees Celsius $(\mu \mathrm{S} / \mathrm{cm}$ at $\left.25^{\circ} \mathrm{C}\right)$.

Concentrations of chemical constituents in water are given either in milligrams per liter (mg/L) or micrograms per liter $(\mu \mathrm{g} / \mathrm{L})$. 


\title{
Ground-Water Quality in the Vicinity of Coal-Refuse Areas Reclaimed with Biosolids in Fulton County, Illinois
}

\author{
By William S. Morrow
}

\section{Abstract}

The Metropolitan Water Reclamation District of Greater Chicago has applied biosolids, followed by revegetation, to reclaim three coal-refuse areas. Most of the reclamation at the three sites was done from 1989 through 1992, and included the application of lime, clay, and various loads of biosolids up to 1,000 dry tons per acre. Water samples collected from 12 monitoring wells installed in the vicinity of the three reclaimed coal-refuse areas were analyzed to better understand the hydrogeology and water-quality effects.

Ground water probably flows along preferential paths in the disturbed coal-refuse areas, and is impeded by undisturbed glacial till. Most of the samples contained elevated concentrations of sulfate, iron, and manganese, constituents associated with ground water in coal-mined areas. Concentrations of aluminum, cadmium, nickel, or zinc were somewhat elevated in samples from four wells, and greatest in water samples with $\mathrm{pH}$ less than 5. The smaller nutrient concentrations indicate that the applied biosolids are not identifiably affecting nutrients or metal concentrations in shallow ground water near the refuse piles. The coal refuse likely is the primary influence on the chemical characterization of ground-water in the area.

\section{Introduction}

The Metropolitan Water Reclamation District of Greater Chicago (MWRD) began operation of the Fulton County site in early 1971 to reclaim mine spoil land using biosolids. Sewage and sludge from the greater Chicago area have been transported to the MWRD facility and treated, initially as digested liquid biosolids, and later as air-dried biosolids, starting in the mid-1980s (Tian and others, 2006). The resulting biosolids and supernatant liquid have been applied to agricultural fields, former coal mines, and coal-refuse areas on the facility to reclaim the land. The application of biosolids to coal-refuse areas ceased in 2002, and to the entire site in 2004. Monitoring of surface-water quality and ground-water quality in the MWRD-owned area began in the early 1970s and currently (2007) continues, but effects on ground-water quality immedi- ately adjacent to the coal-refuse areas are relatively unknown. To better understand these effects, the U.S. Geological Survey (USGS), in cooperation with the MWRD, conducted a study of ground-water quality in the vicinity of three coal-refuse areas on which biosolids have been applied at the MWRD facility. Previous work to characterize the effects of groundwater quality from biosolids applications on formerly mined land generally indicate that the leaching potential of nitrate and metals is greatest when the biosolids are first applied, but long-term effects are not expected (Stehouwer and others, 2006; Daniels and Haering, 2000; Haering and others, 2000). An investigation of the effects of biosolids applied on formerly mined land in Pennsylvania (Stehouwer and others, 2006) indicated that nutrients and trace-element leaching were greatest during the first year of application, then attenuated. An investigation of biosolids effects on ground water in the Colorado area (Yager and others, 2004) indicated that there were no significant upward trends in concentrations of cadmium, chromium, lead, nickel, or zinc in ground water in biosolids application areas. Another recent investigation (McAuley and Kozar, 2006) on ground-water quality in unmined areas and near surface coal mines in the Appalachian region indicated that significantly greater median concentrations of aluminum, ammonia, iron, manganese, sulfate, and zinc were present in ground water from mined areas than in ground water from unmined areas, and that iron and manganese were ubiquitous throughout mined areas. Aluminum, manganese, sulfate, and zinc had greatest concentrations within 500 feet (ft) of coal-mined areas, but decreased to background conditions at distances greater than $1,000 \mathrm{ft}$.

\section{Purpose and Scope}

This report describes the results of a water-quality investigation at the three coal-refuse areas at the MWRD land reclamation site located in Fulton County, Illinois (fig. 1). Hydrogeologic and water-quality data collected near three coal-refuse areas that were reclaimed by biosolids applications are presented and analyzed. Included are data from 12 wells installed for the study and sampled during September and November 2006. Summary statistics of the water-quality data are discussed and related to background water-quality conditions. 


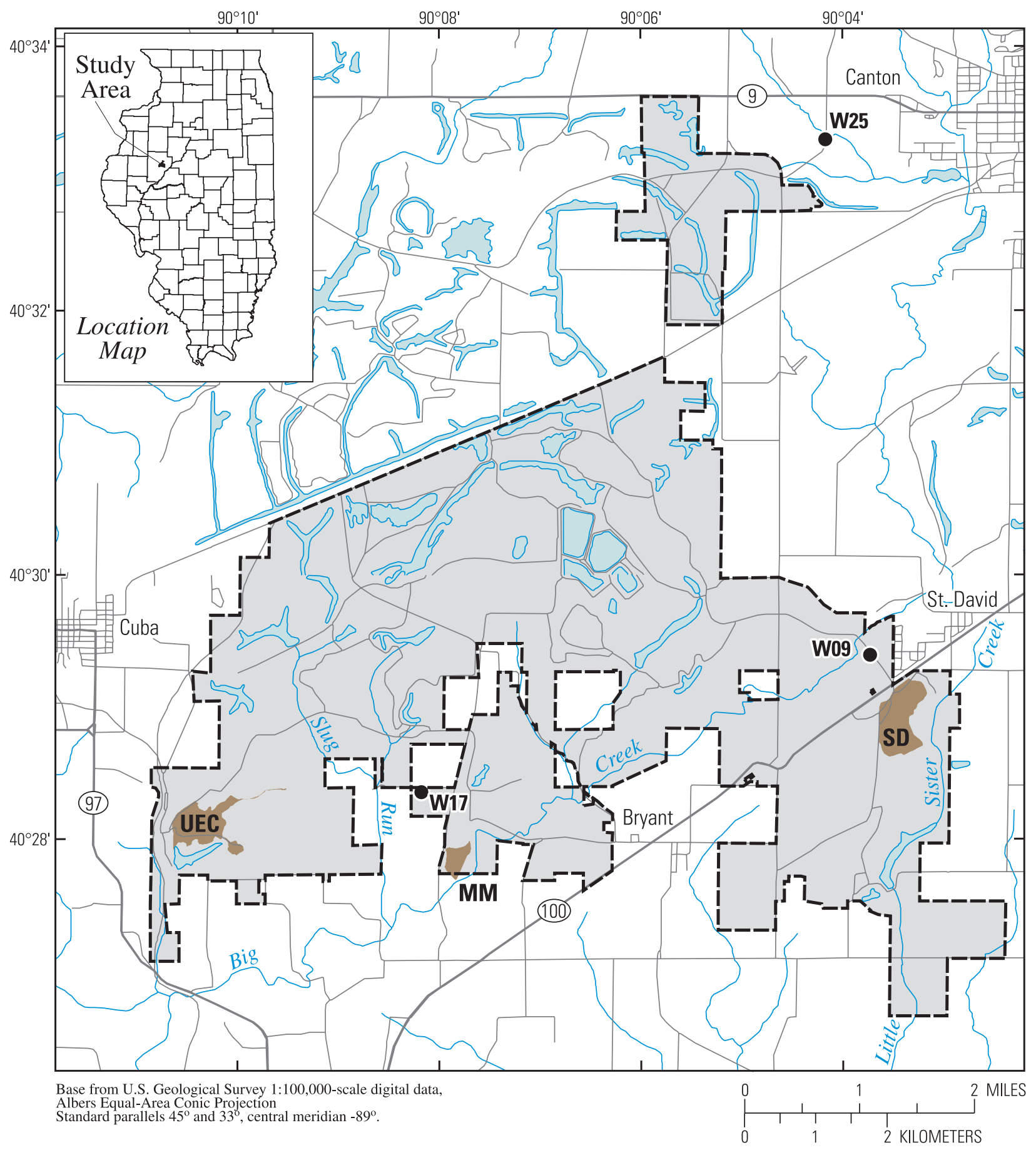

\section{EXPLANATION}

___-_ Metropolitan Water Reclamation District boundary

UEC Coal refuse area and identifier

W17 Background well and identifier

Figure 1. Location of the Metropolitan Water Reclamation District of Greater Chicago property in Fulton County, Illinois. 


\section{Background}

The study area is in Fulton County of western Illinois (fig. 1) within the Galesburg Plain subsection of the Till Plains section of the Central Lowland physiographic province (Willman and others, 1975). Before mining, the geology of the area consisted of loess overlying Illinois glacial episode, or older, drift. Underlying the glacial drift is the Carbondale Formation of the Pennsylvanian System, consisting of alternating layers of coal, limestone, shale, and sandstone. Areas in Fulton County have been mined for coal, using surface- and underground-mining methods. Surface mining began by removing all material overlying the Springfield, Colchester, or other coal seams in the Carbondale Formation. The excavated overburden material was redeposited as irregular ridges and valleys, and the resultant excavations often became lakes. The landscape and local drainage patterns were rearranged over much of the area (Coupe and Macy, 1993; Patterson, 1982; Patterson and others, 1982; Zuehls and others, 1981).

During 1970-71, the MWRD purchased 15,527 acres of land in Fulton County roughly bordered by the towns of St. David, Canton, Cuba, and Bryant (fig.1) for the purpose of disposing of sewage sludge generated by the greater Chicago metropolitan area and applying biosolids to reclaim those lands. This land was surface mined primarily for coal (78 percent of the land) from the 1920s to the 1960s. Approximately 4,400 acres were developed into agricultural fields for crop production. Biosolids were applied to these fields from 1972 through 2004. The average amount of cumulative biosolids applied on these agricultural fields was approximately 390 tons per acre (Patterson, 1982; Tian and others, 2006).

Three primary coal-refuse areas were created adjacent to, or on, operating coal mines and areas for cleaning and processing coal. They are the United Electric Company, Morgan Mine, and the St. David coal-refuse areas (fig. 1, fig. 2). The United Electric Company, Morgan Mine, and St. David areas are located in the southwest, south central, and southeast parts of the study area, and are 101,27, and 120 acres in area, respectively. The United Electric Company area was operated from 1924 through 1971; the Morgan Mine area was used from 1942 through 1955; and the St. David area was used from 1936 through 1967. In all three areas, coal was processed and cleaned from the Springfield coal seam by strip mining (Illinois State Geological Survey, 2006). The glacial drift, shale, and residual coal removed were displaced, then redeposited unsorted. To reclaim the area, the MWRD graded and recontoured the land to decrease erosion. Various amounts of lime, clay, and biosolids were applied in layers, primarily from 1989 through 1992. Maximum application rates were 70 dry tons per acre of lime, 538 cubic yards per acre of clay, and 1,000 dry tons per acre of biosolids. The reclaimed areas were then revegetated with a forage mixture.

\section{Study Methods}

\section{Well Installations}

A direct hydraulic-push rig mounted on a four-wheeldrive truck was used to install 12 wells. Using a 2-in. diameter sampler, cores were collected continuously and the geology of the unconsolidated deposits was logged down to the first water-yielding unit. A 1 -in. diameter by 5 -ft long polyvinyl chloride (PVC) well screen with 1-in. diameter PVC casing was installed in the core hole. A sand filter pack was added to about $1 \mathrm{ft}$ above the top of the screen, and the remainder of the annulus was sealed to land surface with fine-granular hydrated bentonite. Occasionally, a 1-in. diameter probing rod was used to determine depth to bedrock and presence of water-yielding deposits before continuous coring was attempted.

Using this method, 12 wells were installed in September 2006. Five wells were installed at the United Electric Company area, three wells at the Morgan Mine area, and four wells at the St. David area (fig. 2). There also were two bore holes that did not yield water. One bore hole was at the west edge of the St. David area and the other was south of the coal-refuse pile at the United Electric Company area (fig. 2). The well construction and boring logs are listed in appendix 1, at the back of this report.

Three previously installed wells were selected as background wells. These wells were installed by the MWRD during the 1970s as part of a general monitoring program for the entire MWRD facility. These wells are not in coal-refuse or biosolids application areas, but may be in areas of former coal mining activities, as virtually the entire study area is affected by coal mining, based on observed topography. These wells (W09, $47 \mathrm{ft}$ deep; W17, $51 \mathrm{ft}$ deep; W25, $31.5 \mathrm{ft}$ deep) are deeper than the monitoring wells installed for this study and generally are topographically upgradient from the coal-refuse areas. Well W09 is approximately 2,000 ft north from the St. David area, W17 is approximately 2,900 ft northwest from the Morgan Mine area, and W25 is more than 3 miles (mi) generally north of all areas.

\section{Water-Sample Collection and Analysis}

Initial water samples were collected from the installed monitoring wells in September 2006, within 1 week of well construction; resampling of three wells was completed in November 2006. Using a peristaltic pump and Teflon tubing, the wells first were developed to maximize water production, reduce turbidity, and remove unrepresentative ground water. Before sampling, three well-casing volumes of water were purged from the well, and dissolved oxygen, specific conductivity, $\mathrm{pH}$, temperature, and turbidity were monitored continuously until they stabilized (measurements were made with an In-Situ Troll 9000 water-quality meter). Turbidity was quantified using a Hach $2100 \mathrm{P}$ instrument that measures 

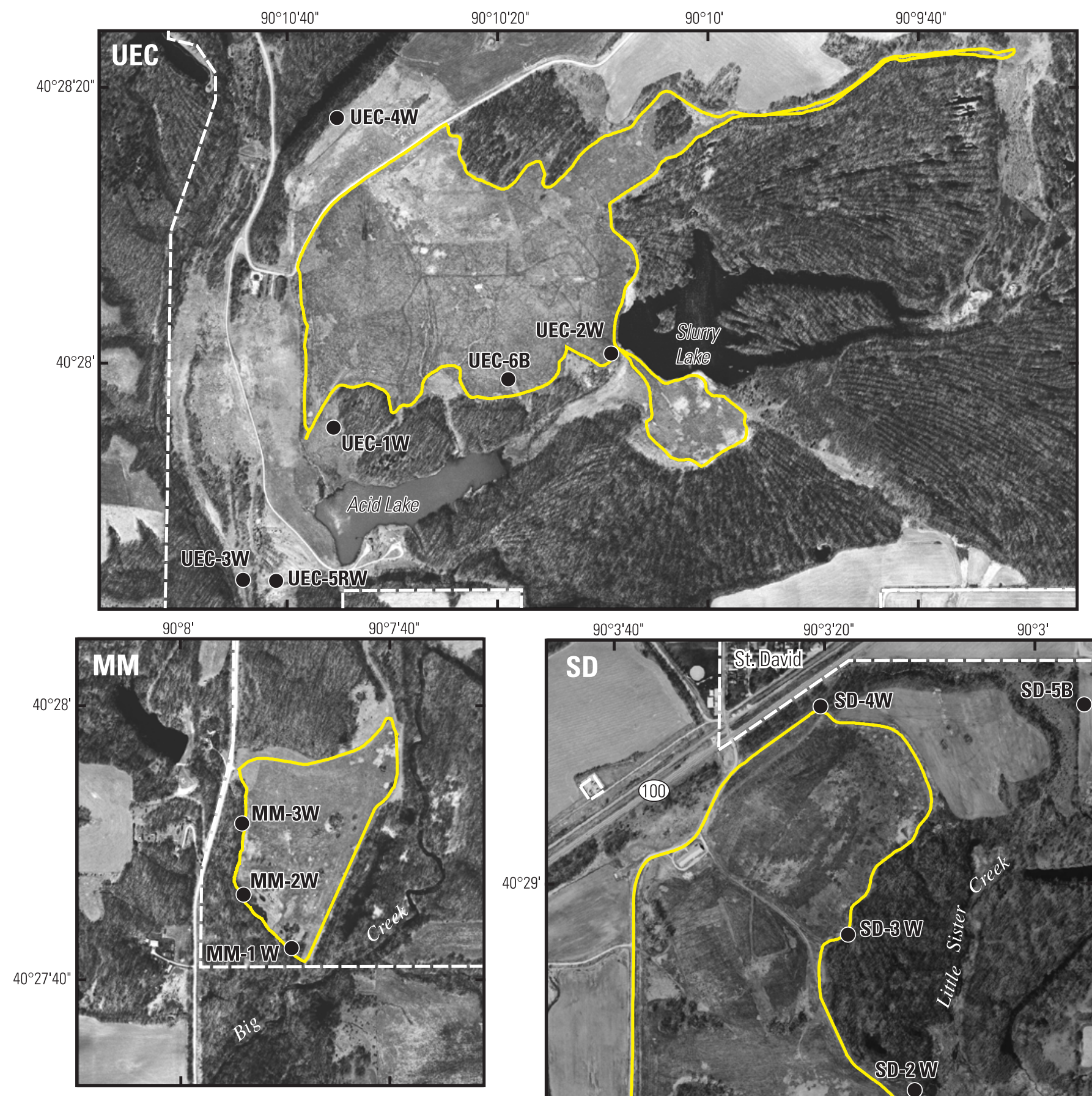

\section{EXPLANATION}

Approximate Metropolitan Water Reclamation District boundary

Coal refuse area

MM-3W Background well or boring and identifier

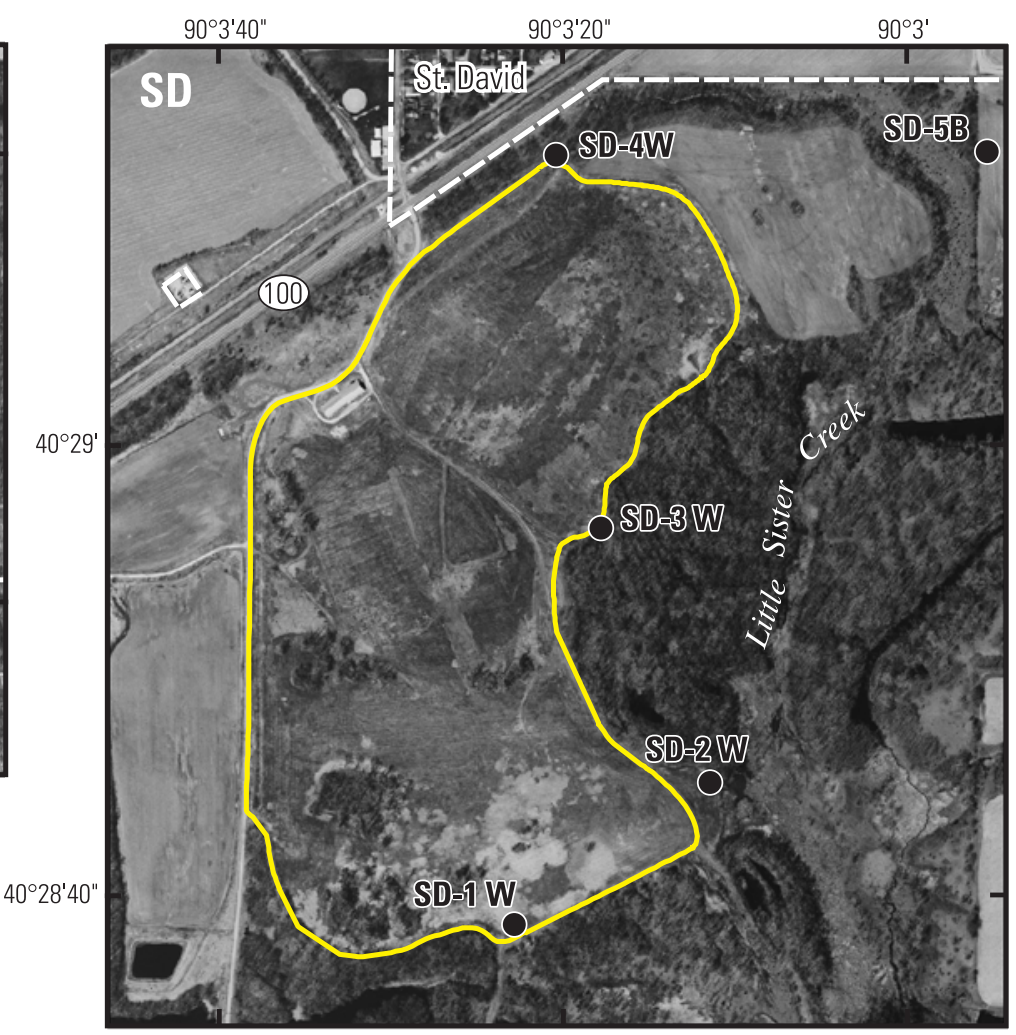

Base from U.S. Geological Survey 1:100,000-scale digital data, Albers Equal-Area Conic Projection, Standard parallels $45^{\circ}$ and $33^{\circ}$, central meridian $-89^{\circ}$. Scale shown is $1: 13,000$

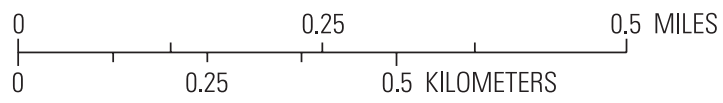

Figure 2. Location of coal-refuse areas in Fulton County, Illinois. 
scattered light, meeting the U.S. Environmental Protection Agency (USEPA) 180.1 method criteria (U.S. Environmental Protection Agency, 1993). The Hach instrument uses several detectors to increase the measurement range, and an algorithm using the multiple detection results is used to calculate a final value. Units are in nephelometric turbidity ratio units (NTRUs), which are equivalent to nephelometric turbidity units (NTUs). One well, SD-1W, did not produce enough water to allow continuous monitoring of these parameters during the purge with the peristaltic pump and collect a sample. Water from this well was obtained by pumping the well dry while monitoring the parameters, and collecting a sample for analysis the next day.

Samples for analyses of dissolved-metals were filtered with a 0.45 -micrometer $(\mu \mathrm{m})$ pore size disposable capsule filter and preserved with nitric acid. Samples for nutrients (nitrogen species) analyses were collected unfiltered and preserved with sulfuric acid. Samples for analyses of acidity (base neutralizing capacity), $\mathrm{pH}$, and sulfate were collected unfiltered and not preserved. All samples were analyzed by PDC Laboratories in Peoria, Illinois, for nutrients (ammonia and nitrate plus nitrite - as nitrogen), dissolved metals (aluminum, cadmium, chromium, copper, iron, lead, manganese, nickel, and zinc), sulfate, and acidity. Nitrate plus nitrite as nitrogen was analyzed using the automated cadmium-reduction method; ammonia was analyzed using the distillation/ automated phenate method. Metals were analyzed by inductively coupled plasma-mass spectrometry. Sulfate was analyzed using ion chromatography. Acidity was analyzed using the titrimetric method in milligrams per liter $(\mathrm{mg} / \mathrm{L})$ as $\mathrm{CaCO}_{3}$ (John LaPayne, PDC Laboratories; written communication, 2006). All samples were chilled and analyzed within required holding times, except for laboratory $\mathrm{pH}$, which was exceeded for all samples.

One set of blank samples and one set of replicate samples were included with the samples collected in September for quality assurance and quality control. There were no detections in the blank samples at or above the reporting levels. Replicate samples were identical for metals, sulfate, and nutrient analyses. Replicate samples differed by 2 percent for lab $\mathrm{pH}$ and by 20 percent for acidity. Results from these samples indicate that the data are of acceptable quality, with the possible exception of acidity.

Three wells were resampled in November 2006 to confirm $\mathrm{pH}$ measurements less than 5.0 and/or elevated concentrations of aluminum, cadmium, nickel, and zinc. Metal concentrations were similar for all constituents, generally having less than 20 percent variability.

The three background wells (W09, W17, and W25) were sampled quarterly by MWRD personnel beginning in 1972 as part of the environmental monitoring system for the site. These samples were filtered for metals analyses. Beginning in 1999, several reporting levels for laboratory analyses of metals decreased substantially. Water-quality data from these wells indicate that coal mining effects likely affected the ground water most in 1972 for several constituents, then the effects attenuate over several years. For the purposes of this report, the 8 years of historical water-quality data for these wells (February 1997 through September 2006) are assumed to be representative of background (unaffected by applied biosolids) water-quality conditions. Historical background results that are below the reporting level for the analysis are given as the reporting level for statistical purposes. Data for these background wells are in appendix 2, at the back of this report.

\section{Statistical Methods}

Concentration ranges and medians were calculated for each constituent for samples collected in September 2006. The results from the three wells resampled in November 2006 were not used, because to include them would skew the statistical calculations. The small number of samples (12) and many non-detections for these samples limit the interpretation of these correlations; therefore, correlations are not included in this report.

For the historical background well data, ranges were calculated for each constituent. Because of the limited information on reporting levels for analyses of samples from the background wells, median values were calculated using the reporting level for censored values.

\section{Hydrology}

The United Electric Company area is generally bounded to the south by Big Creek, the major stream on the MWRD property, and bounded to the east by Slug Run, a tributary to Big Creek (fig.1). To the west, the United Electric Company area is bounded by an unnamed tributary to Big Creek that flows approximately parallel to the bed of an abandoned railroad. Five monitoring wells were installed at the United Electric Company area, all in reworked refuse (fig. 2). Well depths in the United Electric Company area ranged from 11.0 to 21.9 $\mathrm{ft}$ below land surface (bls). Depth to water ranged from 5.87 to $14.16 \mathrm{ft}$ bls at time of sampling (table 1). Wells UEC-1W and UEC-2W, installed at the south edge of the refuse pile in reworked deposits, yielded water at well depths of less than 22 $\mathrm{ft}$. No water was detected during coring in the UEC-6B bore hole to $32 \mathrm{ft}$ deep, approximately $500 \mathrm{ft}$ east of UEC-1W and $1,600 \mathrm{ft}$ west of UEC-2W. The geology at this bore hole seems to be undisturbed glacial till down to shale bedrock at $32 \mathrm{ft}$ bls. The fine-grained till deposits consistently are unsaturated because of their low permeability, and the coal-refuse materials consistently are saturated. This indicates that ground-water flow primarily occurs in the unconsolidated coal refuse and spoils at all three coal-refuse areas.

Well UEC-4W, north from the United Electric Company refuse area, is $20.0 \mathrm{ft}$ deep with a water level of $14.04 \mathrm{ft}$ bls at time of sampling. Initial probing before installation of well UEC-4W indicated a water-yielding zone of coarse material 
Table 1. Field measurements, lab pH, and construction characteristics for shallow ground-water wells in coal-refuse areas in Fulton County, Illinois, fall 2006.

[ $\mu \mathrm{S} / \mathrm{cm}$, microsiemens per centimeter; mg/L, milligrams per liter; NTRU, nephelometric turbidity ratio units; ft bls, feet below land surface; --, no data]

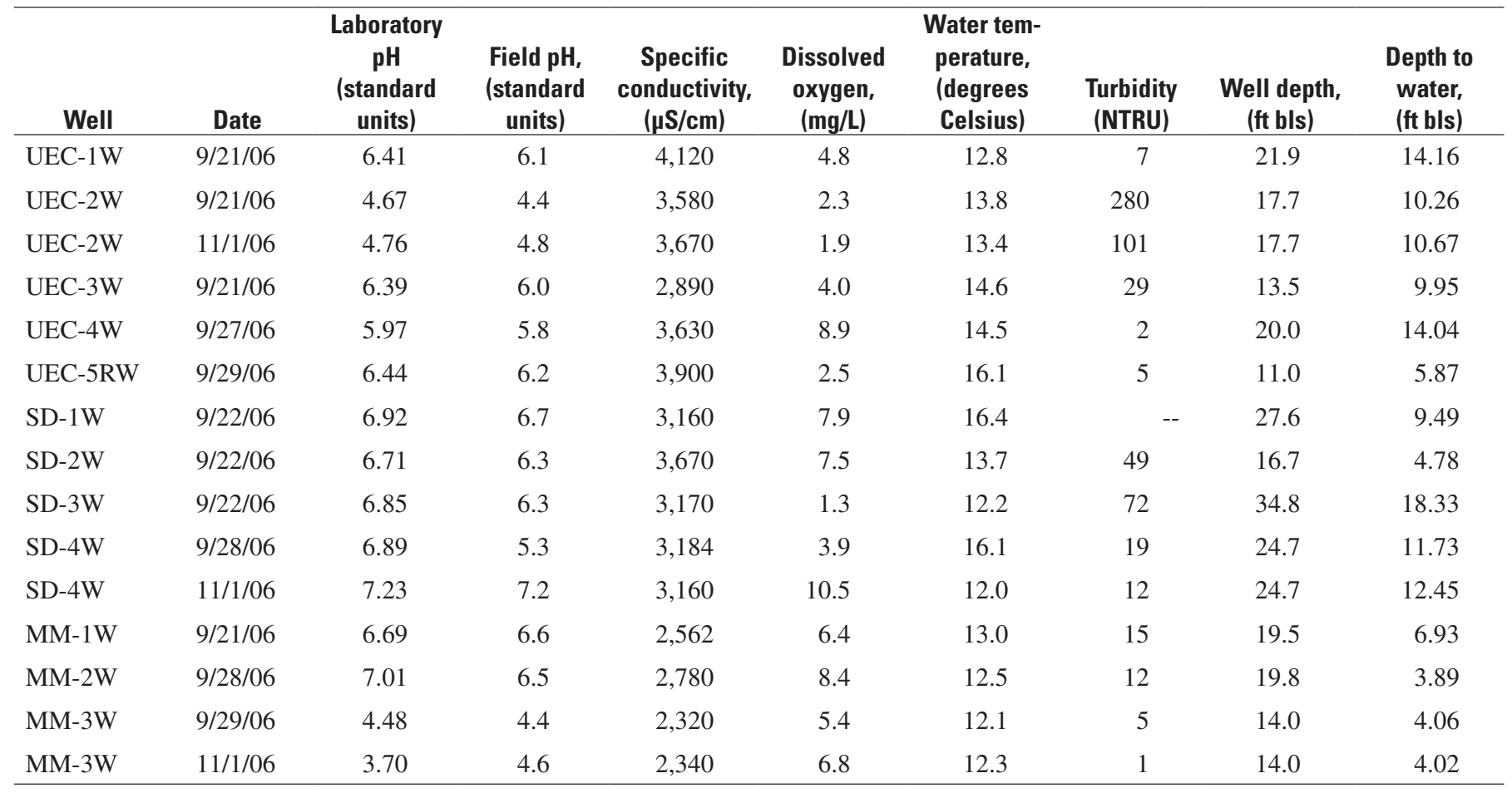

from 44 to $48 \mathrm{ft}$ with a depth to water of $31 \mathrm{ft}$ bls. Five subsequent attempts to install a well in this deep water-yielding zone failed because buried rocks or debris limited penetration to $35 \mathrm{ft}$ deep. The absence of water at $35 \mathrm{ft}$ indicates that the deeper water-yielding area is confined.

The Morgan Mine area is bounded generally to the south and east by Big Creek, and to the north and west by uplands. Three wells were installed on the west and southwest side of the area in coal-refuse deposits (fig. 2). Well depths in the Morgan Mine area ranged from 14.0 to $19.8 \mathrm{ft}$ bls. Depth to water ranged from 3.89 to $6.93 \mathrm{ft}$ bls at time of sampling.

The geology at well W17, an upland monitoring well installed in 1971 approximately 2,900 ft north of the Morgan Mine area, is $43 \mathrm{ft}$ of undisturbed glacial till, underlain by limestone bedrock. The well was screened from 46 to $51 \mathrm{ft}$ bls in the limestone. The glacial till at well W17 does not yield water, as indicated by driller's log.

The St. David area generally is bounded by the headwaters of Little Sister Creek to the east and south. Four wells were installed in the St. David area, all in coal refuse near the perimeter of the main refuse pile on the north, south, and east sides (fig. 2). Well depths in the St. David area ranged from 16.7 to $34.8 \mathrm{ft}$ bls. Depth to water ranged from 4.78 to 18.33 $\mathrm{ft}$ bls at the time of sampling. Well SD-4W (well depth of 24.7 $\mathrm{ft}$ ), installed at the north edge of the refuse pile, yielded water at $11.73 \mathrm{ft}$ bls. However, no water was present in UEC-6B, a $33.5 \mathrm{ft}$ deep bore hole, approximately $1,800 \mathrm{ft}$ east of SD-4W. The geology at this hole was undisturbed glacial till to $33.5 \mathrm{ft}$ deep bls where shale bedrock was encountered. The till deposits seemed unsaturated and poorly permeable.

Borings UEC-6B, at the southern edge of the United Electric Company refuse pile and near the tree line, and boring SD-5B, several hundred feet west from the St. David refuse pile (fig. 2), were beyond the coal-refuse area in undisturbed glacial till and yielded no water. The best waterproducing zones, based on the 12 well installations, were the coal-refuse deposits. Ground water appears to flow preferentially through the coal refuse and is impeded by undisturbed glacial till. Shallow ground-water discharge presumably is to the nearby streams and lakes that are topographically downgradient of the refuse areas. Ground-water flow at the United Electric Company area may discharge into Slug Run and Big Creek; the Morgan Mine area ground-water flow may discharge into Big Creek; and the St. David area ground-water flow may discharge into Little Sister Creek (fig. 1).

\section{Ground-Water Quality in the Vicinity of Coal-Refuse Areas}

Ground-water samples were collected at the three coalrefuse areas in September 2006. Laboratory water-quality analytical results for the samples are listed in tables 2 and 3. To evaluate the relative concentrations of the constituents 
Table 2. Acidity, sulfate, and nutrient concentrations for shallow ground-water wells in coal-refuse areas in Fulton County, Illinois, fall 2006.

[mg/L, milligrams per liter; <, less than]

\begin{tabular}{lccccc}
\hline Well & Sampling date & $\begin{array}{c}\text { Acidity, } \\
\text { (mg/L as calcium } \\
\text { carbonate) }\end{array}$ & $\begin{array}{c}\text { Total sulfate, } \\
\text { (mg/L) }\end{array}$ & $\begin{array}{c}\text { Nitrate plus nitrite } \\
\text { as nitrogen, } \\
\text { (mg/L) }\end{array}$ & $\begin{array}{c}\text { Ammonia as nitrogen, } \\
\text { (mg/L) }\end{array}$ \\
\hline UEC-1W & $9 / 21 / 06$ & 550 & 2,700 & $<0.02$ & 2.00 \\
UEC-2W & $9 / 21 / 06$ & 550 & 2,900 & $<.02$ & 0.51 \\
UEC-2W & $11 / 1 / 06$ & 770 & 2,900 & .02 & .54 \\
UEC-3W & $9 / 21 / 06$ & 200 & 1,800 & $<.02$ & .38 \\
UEC-4W & $9 / 27 / 06$ & 590 & 2,500 & $<.02$ & 2.70 \\
UEC-5RW & $9 / 29 / 06$ & 460 & 2,500 & $<.02$ & 3.20 \\
SD-1W & $9 / 22 / 06$ & 110 & 1,800 & $<.02$ & .23 \\
SD-2W & $9 / 22 / 06$ & 130 & 2,200 & .03 & .11 \\
SD-3W & $9 / 22 / 06$ & 140 & 1,800 & .03 & .68 \\
SD-4W & $9 / 28 / 06$ & 110 & 1,700 & $<.02$ & .62 \\
SD-4W & $11 / 1 / 06$ & 100 & 1,800 & .02 & .57 \\
MM-1W & $9 / 21 / 06$ & 140 & 1,400 & $<.02$ & 1.60 \\
MM-2W & $9 / 28 / 06$ & 82 & 1,600 & $<.02$ & .16 \\
MM-3W & $9 / 29 / 06$ & 340 & 1,500 & $<.02$ & 1.30 \\
MM-3W & $11 / 1 / 06$ & 390 & 1,600 & .02 & 1.20 \\
\hline
\end{tabular}

Table 3. Dissolved metals concentrations for shallow ground-water wells in coal-refuse areas in Fulton County, Illinois, fall 2006.

[mg/L, milligrams per liter; $<$, less than]

\begin{tabular}{lcccccccccc}
\hline Well & $\begin{array}{c}\text { Sampling } \\
\text { date }\end{array}$ & $\begin{array}{c}\text { Aluminum, } \\
(\mathbf{m g} / \mathbf{L})\end{array}$ & $\begin{array}{c}\text { Cadmium } \\
(\mathbf{m g} / \mathbf{L})\end{array}$ & $\begin{array}{c}\text { Chromium, } \\
(\mathbf{m g} / \mathbf{L})\end{array}$ & $\begin{array}{c}\text { Copper, } \\
(\mathbf{m g} / \mathbf{L})\end{array}$ & $\begin{array}{c}\text { Iron, } \\
(\mathbf{m g} / \mathbf{L})\end{array}$ & $\begin{array}{c}\text { Lead, } \\
(\mathbf{m g} / \mathbf{L})\end{array}$ & $\begin{array}{c}\text { Manga- } \\
\text { nese, } \\
(\mathbf{m g} / \mathbf{L})\end{array}$ & $\begin{array}{c}\text { Nickel, } \\
(\mathbf{m g} / \mathbf{L})\end{array}$ & $\begin{array}{c}\text { Zinc, } \\
(\mathbf{m g} / \mathbf{L})\end{array}$ \\
\hline UEC-1W & $9 / 21 / 06$ & 0.02 & $<0.001$ & $<0.004$ & $<0.003$ & 190 & $<0.001$ & 1.1 & 0.02 & 0.027 \\
UEC-2W & $9 / 21 / 06$ & 14.0 & .38 & $<.004$ & .034 & 20 & $<.001$ & 150 & 2.0 & 40 \\
UEC-2W & $11 / 1 / 06$ & 12.0 & .38 & .004 & .031 & 18 & .001 & 150 & 1.8 & 38 \\
UEC-3W & $9 / 21 / 06$ & .02 & .006 & $<.004$ & $<.003$ & 0.17 & $<.001$ & 25 & .20 & 2.0 \\
UEC-4W & $9 / 27 / 06$ & .27 & $<.001$ & .004 & .003 & 260 & $<.001$ & 36 & .03 & .37 \\
UEC-5RW & $9 / 29 / 06$ & .03 & $<.003$ & .004 & .003 & 170 & $<.001$ & 3.1 & .05 & .12 \\
SD-1W & $9 / 22 / 06$ & $<.01$ & $<.001$ & $<.004$ & $<.003$ & $<.01$ & $<.001$ & 12 & .05 & .012 \\
SD-2W & $9 / 22 / 06$ & $<.01$ & .002 & $<.004$ & .004 & $<.01$ & $<.001$ & 25 & .05 & .020 \\
SD-3W & $9 / 22 / 06$ & $<.01$ & $<.001$ & $<.004$ & $<.003$ & 11 & $<.002$ & 9.9 & .06 & .032 \\
SD-4W & $9 / 28 / 06$ & $<.02$ & $<.001$ & $<.004$ & $<.003$ & 18 & $<.003$ & 9.3 & .03 & .019 \\
SD-4W & $11 / 1 / 06$ & .01 & .001 & .004 & .003 & 14 & .001 & 12 & .03 & .032 \\
MM-1W & $9 / 21 / 06$ & $<.03$ & $<.001$ & $<.004$ & $<.003$ & 68 & $<.004$ & 12 & .02 & $<.006$ \\
MM-2W & $9 / 28 / 06$ & $<.04$ & $<.001$ & $<.004$ & $<.003$ & 44 & $<.005$ & 1.5 & .02 & $<.006$ \\
MM-3W & $9 / 29 / 06$ & 7.6 & .13 & $<.004$ & $<.003$ & 64 & $<.007$ & 34 & .77 & 8.7 \\
MM-3W & $11 / 1 / 06$ & 9.0 & .14 & .004 & .003 & 68 & .002 & 38 & .70 & 8.2 \\
\hline
\end{tabular}


analyzed, the USEPA drinking water standards (U.S. Environmental Protection Agency, 2006) were used for context; however, these samples are from monitoring wells, which are not intended for potable use. Determination of whether or not a compound was a likely biosolid contaminant was based on the U. S. Environmental Protection Code of Federal Regulations, Part 503 requirement of monitoring biosolid land applications for arsenic, cadmium, chromium, copper, lead, mercury, nickel, selenium, and zinc (U.S. Environmental Protection Agency, 1995).

\section{Field Parameters}

The September specific conductivity values ranged from 2,320 to 4,120 microsiemens per centimeter ( $\mu \mathrm{S} / \mathrm{cm})$, with a median of $3,180 \mu \mathrm{S} / \mathrm{cm}$ for all wells, indicating relatively high dissolved solids concentrations compared to undisturbed shallow ground water in Illinois. Zuehls and others (1981) developed a relation between dissolved solids and specific conductivity for surface waters with high sulfate concentrations (generally greater than $500 \mathrm{mg} / \mathrm{L}$ ) in the Fulton County area using the equation:

Dissolved solids in $\mathrm{mg} / \mathrm{L}=0.77 *$ Specific Conductivity in $\mu \mathrm{S} / \mathrm{cm}$ (standard error of $128 \mathrm{mg} / \mathrm{L}$ ).

As applied to the ground-water data for this study, this general relation indicates that dissolved solids in the ground water could range from approximately 1,800 to $3,200 \mathrm{mg} / \mathrm{L}$.

The September field $\mathrm{pH}$ values ranged from 4.4 to 6.7 , with a median of 6.2. The field measurements differed with laboratory measured values by $0.1-1.6$ units (laboratory measurements for $\mathrm{pH}$ exceeded holding times for analysis, which may account for much of the disparity).

The laboratory and field $\mathrm{pH}$ values from the well SD-4W sample differed by 1.6 standard units (field; 5.3; laboratory; 6.9). When well SD-4W was resampled, lab and field measurements were 7.2. Laboratory $\mathrm{pH}$ analysis time exceedances may be responsible, or the laboratory or field $\mathrm{pH}$ meter may have been malfunctioning during the first sample, although the field $\mathrm{pH}$ meter was calibrated that day according to standard procedures (Wilde and others, 2006). It also may be possible that $\mathrm{pH}$ conditions may become more basic with increased pumping because refuse deposits immediately surrounding the well may lower the ground water $\mathrm{pH}$ immediately surrounding the well and drawing in water from a larger zone may increase the $\mathrm{pH}$ of the water withdrawn.

Dissolved oxygen concentrations from the September sampling ranged from 1.3 to 8.9 , with a median value of 5.1 $\mathrm{mg} / \mathrm{L}$. These wells are in low-water-yielding deposits. During purging, the water level may have dropped below the top of the well screen, causing cascading water flow within the screened interval, and thus increased dissolved oxygen. The dissolved oxygen concentrations likely are biased high, based on evidence of pumping conditions and the relatively high concentrations of ammonia in the samples.

Water temperature from the September sampling ranged from 12.1 to 16.4 degrees Celsius $\left({ }^{\circ} \mathrm{C}\right)$, with a median of $13.8^{\circ} \mathrm{C}$. Water temperature may have been affected by solar radiation or air temperature during transit time in the flowthrough chamber of the water-quality meter, but are near typical ground-water temperatures for central Illinois. Turbidity ranged from 2 to 280, with a median of 15 NTRUs. The water from most wells was clear and less than 100 NTRUs, except for samples from UEC-2W.

\section{Nutrients}

Concentrations of total nitrate plus nitrite as nitrogen for the September samples ranged from below the reporting level of 0.02 to $0.03 \mathrm{mg} / \mathrm{L}$, with a median less than the reporting level of $0.02 \mathrm{mg} / \mathrm{L} ; 10$ of the 12 results were below the reporting level of $0.02 \mathrm{mg} / \mathrm{L}$. All concentrations were below the USEPA drinking-water maximum contaminant level (MCL) of $10 \mathrm{mg} / \mathrm{L}$ for nitrate as nitrogen (U.S. Environmental Protection Agency, 2006).

Concentrations of total ammonia as nitrogen for the September samples, ranged from 0.11 to $3.2 \mathrm{mg} / \mathrm{L}$, with a median of $0.65 \mathrm{mg} / \mathrm{L}$. All results were below the USEPA drinkingwater lifetime health advisory of $30 \mathrm{mg} / \mathrm{L}$ (U. S. Environmental Protection Agency, 2006). Ammonia with iron and acidity generally increased as indicated by visual plots (fig. 3).

In samples from the three background wells, total nitrate plus nitrite concentrations ranged from 0.001 to 7.82 , with a median of $0.08 \mathrm{mg} / \mathrm{L}$ (appendix 2). Total ammonia concentrations ranged from 0.009 to 15.6 , with a median of $0.10 \mathrm{mg} / \mathrm{L}$. Biosolids were not applied near these background wells; however, agricultural chemical applications, such as fertilizer, were not documented, but likely. Well W09 and well W17 likely are affected by fertilizer applications in the adjacent agricultural fields. The relatively low concentrations of nitrate plus nitrite and ammonia, and similar background well levels, indicate that the biosolids have not increased nutrients in ground water in the coal-refuse areas.

\section{Dissolved Metals, Total Sulfate, and Acidity}

\section{Dissolved Aluminum}

Aluminum, commonly present in acidic mine-drainage waters (Cravotta and Kirby, 2004; Earle and Callaghan, 1998), was detected at concentrations above reporting levels in six of the 12 September samples, all from the Morgan Mine and United Electric Company wells. Aluminum concentrations ranged from less than the reporting levels $(0.01$ to 0.04$)$ to 14.0, with a median of less than $0.04 \mathrm{mg} / \mathrm{L}$ (table 3 ). The USEPA secondary MCL range for aluminum is $0.05-0.2 \mathrm{mg} / \mathrm{L}$ (U.S. Environmental Protection Agency, 2006). All detections were from wells $20 \mathrm{ft}$ deep or less, except for the sample from 


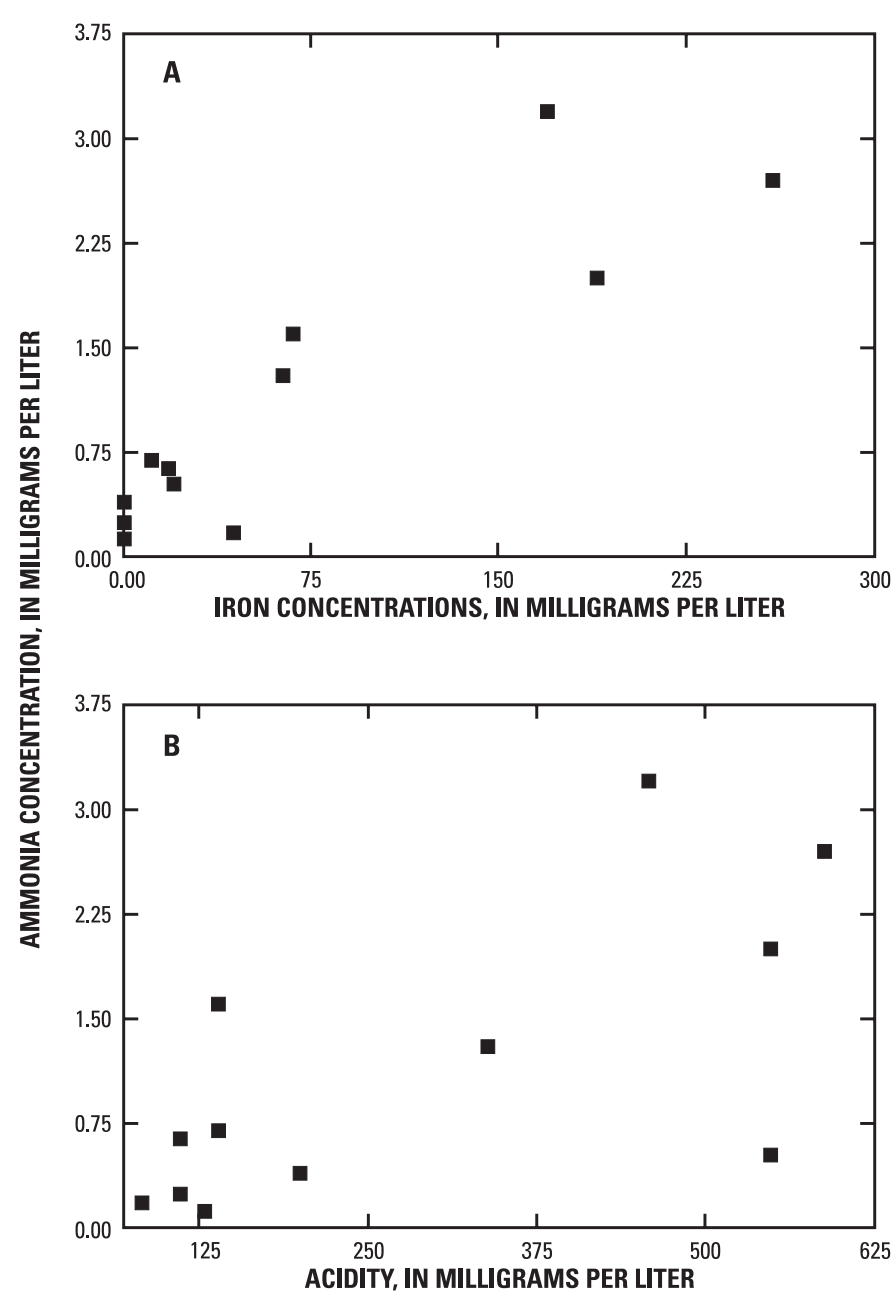

Figure 3. Ammonia concentration as a function of the concentration of $(A)$ iron and $(B)$ acidity from wells near coalrefuse areas.

UEC-1W. Concentrations of three samples $(0.27,7.6$, and $14.0 \mathrm{mg} / \mathrm{L}$ ) exceeded the secondary MCL range; two of these exceedances were in samples from United Electric Company wells; one exceedance was in a sample from a Morgan Mine well.

Dissolved aluminum concentrations from the September samples from MM- $3 \mathrm{~W}$ and UEC-2W were greater than $1 \mathrm{mg} / \mathrm{L}$ (7.6 and 14.0); these samples had a field $\mathrm{pH}$ of 4.4. Resampling in November confirmed these increased concentrations ( 9.0 and $12.0 \mathrm{mg} / \mathrm{L}$ ). Aluminum is most soluble in acidic or basic water, having a minimum solubility at approximately $6.0 \mathrm{pH}$ (Hem, 1985). Aluminum concentrations above the reporting levels occurred in samples with a $\mathrm{pH}$ less than 5.0.

In the samples from the three background wells, aluminum concentrations ranged from 0.05 to 0.21 , with a median of $0.09 \mathrm{mg} / \mathrm{L}$ (appendix 2), indicating that aluminum concentrations in ground water under the refuse areas are still being affected, at least in localized zones of low $\mathrm{pH}$, by the refuse deposits. It is possible that aluminum is from the biosolids, but it is not a required constituent for monitoring biosolids land application (U.S. Environmental Protection Agency, 1995).

\section{Dissolved Cadmium}

Cadmium, commonly present in acidic mine drainage waters (Cravotta and Kirby, 2004; Earle and Callaghan, 1998), was detected at concentrations above reporting levels in four of 12 September samples. All detections were from wells $20 \mathrm{ft}$ deep or less. Cadmium concentrations ranged from below reporting levels ( 0.001 to 0.003 ) to $0.38 \mathrm{mg} / \mathrm{L}$; the median was less than the reporting levels (table 3 ). The USEPA MCL for cadmium is $0.005 \mathrm{mg} / \mathrm{L}$ (U.S. Environmental Protection Agency, 2006). Concentrations in three samples exceeded the MCL (0.006, 0.13 and $0.38 \mathrm{mg} / \mathrm{L}$ ). Two of these exceedances were in samples from the United Electric Company wells; one exceedance was from a Morgan Mine well. The two samples with the greatest concentrations $(0.13$ and $0.38 \mathrm{mg} / \mathrm{L})$ were from MM-3W and UEC-2W, and had $\mathrm{pH}$ less than 5.0.

In the three background well samples, cadmium concentrations ranged from 0.0002 to 0.007 , with a median of $0.001 \mathrm{mg} / \mathrm{L}$ (appendix 2), indicating that cadmium concentrations in ground water under the refuse areas are still being affected, at least in localized zones, by the refuse deposits. It is possible that cadmium is from the biosolids, as it is a required constituent for biosolids land-application monitoring (U.S. Environmental Protection Agency, 1995); however, cadmium also is present in coal-mine drainage waters. With the corresponding low concentrations of nutrients detected, it is likely that cadmium is from the refuse deposits, and not the biosolids.

\section{Dissolved Chromium}

Chromium was detected at the reporting level in 2 of 12 September samples. Chromium concentrations ranged from below the reporting level of 0.004 to $0.004 \mathrm{mg} / \mathrm{L}$ (table 3); the median was less than the reporting level of $0.004 \mathrm{mg} / \mathrm{L}$. Both detections were from wells $20 \mathrm{ft}$ deep or less at the United Electric Company area. No concentrations exceeded the USEPA MCL for chromium of $0.1 \mathrm{mg} / \mathrm{L}$ (U.S. Environmental Protection Agency, 2006). Chromium is a required constituent for biosolids land-application monitoring (U.S. Environmental Protection Agency, 1995), but with concentrations of chromium being detected only at the reporting level of the analyses, it is unlikely that biosolids are affecting chromium concentrations.

In the three background well samples, chromium concentrations ranged from 0.0007 to 0.016 , with a median of 0.002 $\mathrm{mg} / \mathrm{L}$ (appendix 2). This indicates that chromium concentrations in ground water under the refuse areas are not being affected substantially by the refuse deposits or biosolids. 


\section{Dissolved Copper}

Copper, which may be present in acidic mine drainage waters (Earle and Callaghan, 1998), was detected at concentrations above reporting levels in 4 of 12 September samples. Copper concentrations ranged from below the reporting level (0.003) to $0.034 \mathrm{mg} / \mathrm{L}$; the median was below the reporting level of $0.003 \mathrm{mg} / \mathrm{L}$ (table 3). All detections were from wells $20 \mathrm{ft}$ deep or less. Three detections were from samples at United Electric Company wells; one detection was from a sample from a St. David well. No concentrations exceeded the USEPA drinking-water action level for copper of $1.3 \mathrm{mg} / \mathrm{L}$ (U.S. Environmental Protection Agency, 2006). Copper is a required constituent for biosolids land-application monitoring (U.S. Environmental Protection Agency, 1995).

Of the samples collected from the three background wells, copper concentrations ranged from 0.001 to 0.011 , with a median of $0.005 \mathrm{mg} / \mathrm{L}$ (appendix 2). This indicates that copper concentrations in ground water under the refuse areas are not being affected to a substantial extent by the refuse deposits or biosolids.

\section{Dissolved Iron}

Iron, commonly present in acidic mine drainage waters (Cravotta and Kirby, 2004; Earle and Callaghan, 1998), was detected at concentrations above reporting levels in 10 of 12 September samples. Iron concentrations ranged from less than the reporting level of 0.01 to $260 \mathrm{mg} / \mathrm{L}$, with a median of 32 $\mathrm{mg} / \mathrm{L}$ (table 3). Samples from SD-1W and SD-2W had no detectable iron. The secondary USEPA MCL concentration for iron of $0.3 \mathrm{mg} / \mathrm{L}$ was exceeded in nine samples (U.S. Environmental Protection Agency, 2006).

In the three background well samples, iron concentrations ranged from 0.004 to 159 , with a median of $0.08 \mathrm{mg} / \mathrm{L}$ (appendix 2), indicating that iron concentrations in ground water under the refuse areas are still being affected, at least in localized zones, by the refuse deposits. Samples from Well W09 have increased iron concentrations, resulting in a positively biased average. It is possible that iron is from the biosolids, but it is not a required constituent for monitoring biosolids land application (U.S. Environmental Protection Agency, 1995).

\section{Dissolved Lead}

Lead was not detected above reporting levels in any of the 12 September samples. Lead was detected in the November samples from UEC-2W, SD-4W and MM-3W wells at $0.001,0.001$ and $0.002 \mathrm{mg} / \mathrm{L}$, respectively. The reporting levels ranged from 0.001 to $0.007 \mathrm{mg} / \mathrm{L}$ (table 3 ). No concentrations exceeded the USEPA drinking-water action level for lead of $0.015 \mathrm{mg} / \mathrm{L}$ (U.S. Environmental Protection Agency, 2006). Lead is a required constituent for monitoring biosolids land application (U.S. Environmental Protection Agency, 1995).
In the three background well samples, lead concentrations ranged from 0.002 to 0.04 , with a median of $0.01 \mathrm{mg} / \mathrm{L}$ (appendix 2). This indicates that lead concentrations in ground water under the refuse areas are not being affected substantially by the refuse deposits or biosolids.

\section{Dissolved Manganese}

Manganese, commonly present in acidic mine drainage waters, was detected at concentrations above reporting levels in all 12 September samples. Manganese concentrations ranged from 1.1 to $150 \mathrm{mg} / \mathrm{L}$, with a median of $12 \mathrm{mg} / \mathrm{L}$ (table 3). All 12 concentrations exceeded the USEPA lifetime health advisory for manganese of $0.3 \mathrm{mg} / \mathrm{L}$ (U.S. Environmental Protection Agency, 2006).

In the three background well samples, manganese concentrations ranged from 0.03 to 3.9 , with a median of 0.3 $\mathrm{mg} / \mathrm{L}$ (appendix 2), indicating that manganese concentrations in ground water under the refuse areas are still being affected by the refuse deposits. It is possible that the manganese is from the biosolids, but it is not a required constituent for USEPA monitoring of biosolids land application (U.S. Environmental Protection Agency, 1995).

\section{Dissolved Nickel}

Nickel, commonly present in acidic mine drainage waters (Cravotta and Kirby, 2004), was detected at concentrations above reporting levels in all 12 September samples. Nickel concentrations ranged from 0.02 to 2.0, with a median of $0.05 \mathrm{mg} / \mathrm{L}$ (table 3 ). Three samples exceeded the USEPA lifetime health advisory for nickel of $0.1 \mathrm{mg} / \mathrm{L}$ (U.S. Environmental Protection Agency, 2006); two samples were from United Electric Company wells, and one sample was from a Morgan Mine well. All three samples with concentrations above the lifetime health advisory were in wells less than 18 $\mathrm{ft}$ deep.

In the three background well samples, nickel concentrations ranged from 0.002 to 6.4 , with a median of $0.01 \mathrm{mg} / \mathrm{L}$ (appendix 2), indicating that nickel concentrations in ground water under the refuse areas are still being affected, at least in localized areas, by the refuse deposits. It is possible that nickel is from the biosolids, as it is a required constituent for monitoring biosolids land application (U.S. Environmental Protection Agency, 1995). Nickel commonly is present in coal-mine drainage waters, and because of the low concentrations of nutrients detected, it is likely that nickel is from the refuse deposits, and not the biosolids.

\section{Dissolved Zinc}

Zinc, commonly present in acidic mine drainage waters (Cravotta and Kirby, 2004; Earle and Callaghan, 1998), was detected at concentrations above reporting levels in 10 of 12 
September samples. Zinc concentrations ranged from below the reporting level of 0.006 to 40 , with a median of 0.030 $\mathrm{mg} / \mathrm{L}$ (table 3 ). Two samples exceeded the USEPA lifetime health advisory for zinc of $2 \mathrm{mg} / \mathrm{L}$ (U.S. Environmental Protection Agency, 2006); one sample was from a United Electric Company well, and one sample was from a Morgan Mine well. The two highest concentrations occurred in samples with a pH less than 5.0. The three highest concentrations were from wells less than $18 \mathrm{ft}$ deep.

In the three background well samples, zinc concentrations ranged from 0.007 to 5.7 , with a median of $0.37 \mathrm{mg} / \mathrm{L}$ (appendix 2), indicating that zinc concentrations in ground water under the refuse areas are still being affected, at least in localized zones, by the refuse deposits. It is possible that zinc is from the biosolids, but it is not a required constituent for monitoring biosolids land application (U.S. Environmental Protection Agency, 1995),

\section{Total Sulfate}

Total sulfate, commonly present in acidic mine drainage waters (Cravotta and Kirby, 2004; Earle and Callaghan, 1998), was detected at concentrations above reporting levels in all 12 September samples. Sulfate concentrations ranged from 1,400 to $2,900 \mathrm{mg} / \mathrm{L}$, with a median of 1,800 $\mathrm{mg} / \mathrm{L}$ (table 2). Concentrations in all samples exceeded the USEPA drinking-water health-based advisory level for sulfate of $500 \mathrm{mg} / \mathrm{L}$ (U.S. Environmental Protection Agency, 2006). There were general increasing trends of sulfate with specific conductivity and acidity as indicated by visual plots (fig.4).

In the three background well samples, sulfate concentrations ranged from 30 to 2,000, with a median of $160 \mathrm{mg} / \mathrm{L}$ (appendix 2), indicating that sulfate concentrations in ground water under the refuse areas are still being affected by the refuse deposits. Samples from Well W09 have increased sulfate concentrations, resulting in a positively biased average. It is possible that sulfate is from the biosolids, but it is not a required constituent for monitoring biosolids land application (U.S. Environmental Protection Agency, 1995).

\section{Acidity (Base Neutralizing Capacity)}

Acidity ranged from 82 to 590, with a median of 170 $\mathrm{mg} / \mathrm{L}$ as calcium carbonate (table 2). There were general increasing patterns of acidity with ammonia and sulfate as indicated by visual plots (figs. 3 and 4). Acidity samples were not collected at the background wells.

\section{Summary and Conclusions}

During September and November 2006, the U.S. Geological Survey (USGS), in cooperation with the Metropolitan

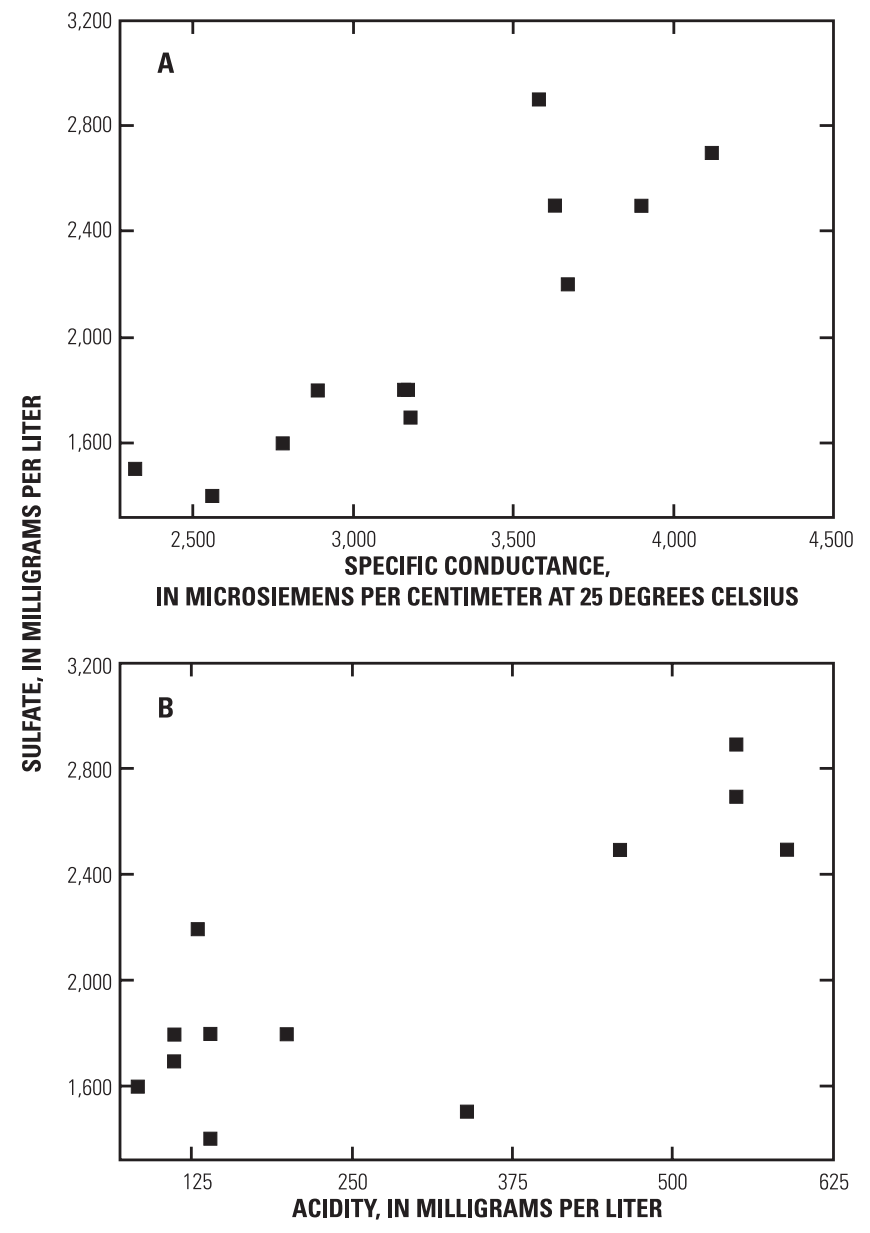

Figure 4. Sulfate concentration as a function of the concentration of $(A)$ specific conductivity and $(B)$ acidity from wells near coal-refuse area.

Water Reclamation District of Greater Chicago (MWRD), installed and sampled 12 monitoring wells to better understand the long-term ground-water-quality effects and hydrogeology near three coal-refuse areas that were reclaimed with biosolids and revegetation at the MWRD land reclamation site in Fulton County, Illinois. Water samples were analyzed for nutrients, dissolved metals, total sulfate, and acidity. Most samples had elevated concentrations (typically above established drinkingwater standards) of sulfate, iron, and manganese, all of which are commonly associated with ground water in coal-mined areas. Concentrations of aluminum, cadmium, nickel, or zinc were elevated in samples from four wells. The largest aluminum, cadmium, nickel, and zinc concentrations were in the two well samples that had $\mathrm{pH}$ values less than 5. Aluminum (except for one sample), cadmium, chromium, and copper were detected only in wells $20 \mathrm{ft}$ deep or less.

The relatively small concentrations of nutrients (nitrate plus nitrite, and ammonia) indicate that in 2006, many years after cessation of biosolids application to the coal-refuse areas, biosolids are not identifiably affecting concentrations of nutri- 
ent or metals in shallow ground water in those areas. The coal refuse likely is the primary contributor of dissolved metals and total sulfate to ground-water chemistry in the area, particularly with respect to iron, manganese, and sulfate concentrations. Ground-water quality does not differ substantially among the three coal refuse study areas. The chemical character of the ground water is related to the coal refuse around the well, the oxidizing-reducing conditions, $\mathrm{pH}$ environment in the refuse, and potentially complex local ground-water flow paths.

Shallow ground water probably flows along preferential paths in the disturbed coal refuse and spoils and is impeded by undisturbed glacial till. This is indicated by the geologic logs, and the presence or absence of water in the installed wells and borings UEC-6B and SD-5B. The general shallow groundwater flow direction probably is toward the creeks present at each area. Ground-water flow at the United Electric Company area may discharge into Slug Run and Big Creek; the Morgan Mine area ground-water flow may discharge into Big Creek; the St. David area ground-water flow may discharge into Little Sister Creek.

Ground-water quality in the area probably will continue to be affected by the coal refuse; however, determining changes in water-quality conditions with time and distance from the refuse pile, as indicated by McAuley and Kozar (2006), were beyond the scope of this study. Investigation by additional installation and sampling of wells at a distance greater than $1,000 \mathrm{ft}$ from the coal-refuse areas, and yearly resampling the 12 installed wells would help to further characterize the shallow hydrogeology and water quality, and assess the ultimate attenuation or discharge to surface-water bodies of coal-refuse and biosolids-related constituents.

\section{Acknowledgments}

Albert Cox of the MWRD supported this study, and along with Josh DeWees, also of the MWRD, provided historical information for the site and water-quality data for previously installed wells. Josh DeWees also coordinated field activities and participated in data collection. Their assistance is greatly appreciated.

\section{References Cited}

Coupe, R.H., and Macy, J.A., 1993, Surface-water and streambed-sediment quality of streams draining surfacemined land reclaimed with sewage sludge, Fulton County, Illinois, 1972-89: U.S. Geological Survey Water-Resources Investigations Report 93-4056, 53 p.

Cravotta, C. A., and Kirby, C. S., 2004, Effects of abandoned coal-mine drainage on streamflow and water quality in the Shamokin Creek Basin, Northumberland and Columbia Counties, Pennsylvania, 1999-2001, US Geological Survey
Water-Resources Investigations Report 03-4311, 53 p: accessed January 23, 2007, at URL http://www.facstaff. bucknell.edu/kirby/0SCRAnewHome/wrir.03-4311.pdf.

Daniels, W.L., and Haering, K.C., 2000, Protocols for Use of Biosolids and Co-Amendments for Mined Land Reclamation. In Proceedings: Mining, Forest \& Land Restoration Symposium. July 17-19: accessed January 17, 2007, at URL http://www.rmwea.org/tech_papers/mine_forest_ land_2000/Daniels.pdf.

Earle, Jane, and Callaghan, Thomas, 1998, Impacts of mine drainage on aquatic life, water uses, and man-made structures, in Brady, B.C., Kania, Timothy, Smith, M.W., and Hornberger, R.J., eds., Coal Mine Drainage Prediction and Pollution Prevention in Pennsylvania: Pennsylvania Department of Environmental Protection, p. 4.1-4.10: accessed January 12, 2007, at URL http://www.ott.wrcc.osmre.gov/ library/pub/cmdpppp.htm.

Haering, K.C., W.L. Daniels and S.E. Feagley. 2000. Reclaiming mined land with biosolids, manures, and papermill sludge in: R.I. Barnhisel and others (eds.), Reclamation of Drastically Disturbed Lands. American Soc. Of Agronomy. Monograph \#41, Madison Wis., 1,082 p.

Hem, J.D., 1985, Study and interpretation of the chemical characteristics of natural water: U.S. Geological Survey Water-Supply Paper 2254, $263 \mathrm{p}$.

Illinois State Geological Survey, 2006, Directory of coal mines in Illinois: Fulton County: Illinois Department of Natural Resources, 38 p.

McAuley, S.D., and Kozar, M.D., 2006, Ground-water quality in unmined areas and near reclaimed surface coal mines in the northern and central Appalachian coal regions, Pennsylvania and West Virginia: U.S. Geological Survey ScientificInvestigations Report 06-5059, $57 \mathrm{p}$.

Patterson, G.L., 1982, Hydrologic effects of storing liquified sewage sludge on strip-mine land, Fulton County, Illinois: U.S. Geological Survey Water-Resources Investigations Report 82-4047, 30 p.

Patterson, G.L., Fuentes, R.F., and Toler, L.G., 1982, Hydrologic characteristics of surface-mined land reclaimed by sludge irrigation, Fulton County, Illinois: U.S. Geological Survey Water-Resources Investigations Report Open-File Report 82-16, 30 p.

Stehouwer, Richard, Day, R.L., Macneal, K.E., 2006, Nutrient and trace element leaching following mine reclamation with biosolids: Journal of Environmental Quality, v. 35, p. $1,118-1,126$.

Tian, Guanglong, Granato, T.C., Pietz, R.I., Carlson, C.R., and Abedin, Zainul, 2006, Effect of long-term application of 
biosolids for land reclamation on surface water chemistry: Journal of Environmental Quality, v. 35, p. 101-113.

U.S. Environmental Protection Agency, 1993. Methods for the determination of inorganic substances in environmental samples: U.S. Environmental Protection Agency Publication EPA/600/R-93/100, 178 p.

U.S. Environmental Protection Agency, Office of Wastewater Management, 1995. A guide to the biosolids risk assessments for the EPA Part 503 Rule: U.S. Environmental Protection Agency Publication EPA 832-B-93-005, 144 p.

U.S. Environmental Protection Agency, Office of Water, 2006, 2006 Edition of the drinking water standards and health advisories: U.S. Environmental Protection Agency Publication EPA 822-R-06-013, 12 p.

Wilde, F.D., Busenberg, E., and Radtke, D.B., 2006, pH (version 1.3): U.S. Geological Survey Techniques of WaterResources Investigations, book 9, chap. A6, section 6.4, accessed July 20, 2007, at URL http://water.usgs.gov/owq/ FieldManual/Chapter6/6.4_ver1.3.pdf.

Willman, H.B., Atherton, Elwood, Buschbach, T.C., Collinson, Charles, Frye, J.C., Hopkins, M.E., Lineback, J.A., and Simon, J.A., 1975, Handbook of Illinois Stratigraphy: Illinois State Geological Survey Bulletin 95, 261 p.

Yager, T.J.B., Smith, D.B., and Crock, J.G., 2004, Effects of surface applications of biosolids on soil, crops, ground water, and streambed sediment near Deer Trail, Colorado, 1999-2003: U.S. Geological Survey Scientific-Investigations Report 04-5289, 93 p.

Zuehls, E.E., Ryan, G.L., Peart, D.B., and Fitzgerald, K.K., 1981, Hydrology of area 25, eastern region, interior coal province, Illinois: U.S. Geological Survey Open-File Report 81-636, 66 p. 

Appendixes 1-2 


\section{Appendix 1. Geologic Boring and Construction Logs}

\section{₹USGS}

\section{Geologic Boring and Construction Log}

Project: MWRD

LOCATION: Morgan Mine

Well ID MM-1W

METHOD : Geoprobe

DATE : $\quad$ 9-20-06

\begin{tabular}{l|l|l|l|l}
$\begin{array}{l}\text { Depth } \\
\text { (feet) }\end{array}$ & Geologic & Geologic description & $\begin{array}{l}\text { Well } \\
\text { construction }\end{array}$ & $\begin{array}{l}\text { Well description } \\
\text { (feet) }\end{array}$
\end{tabular}
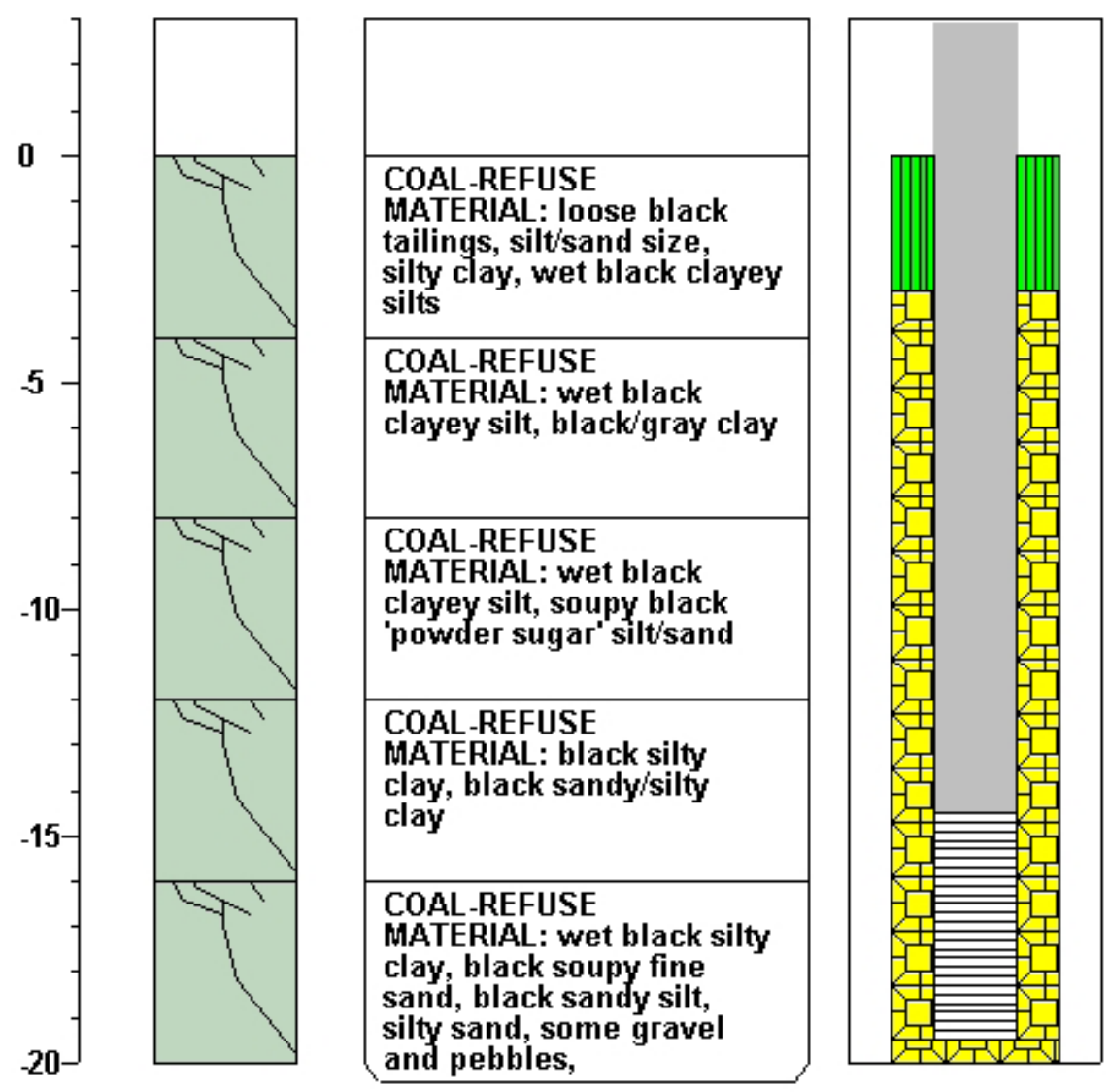

PVC stickup of 2.9

Bentonite from 0 to 3

Filter pack sand from 3 to 5

Natural fill from 5 to 20

Top of screen at 14.5

Bottom of screen at $\mathbf{1 9 . 5}$

Bottom of borehole at 20 
Project: MWRD

LOCAT ION : Morgan Mine

Well ID MM-2W

METHOD : Geoprobe

DATE : 9-22-06

\begin{tabular}{l|l|l} 
Depth & Geologic & Geologic description \\
(feet) & $\log$ &
\end{tabular}

Well construction

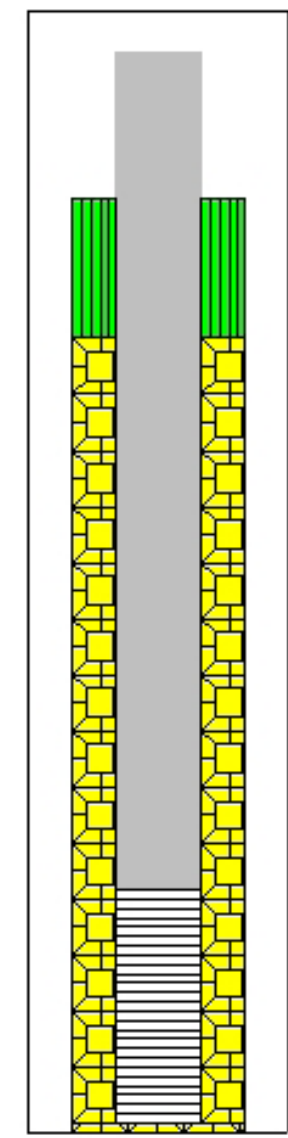

Well description (feet)

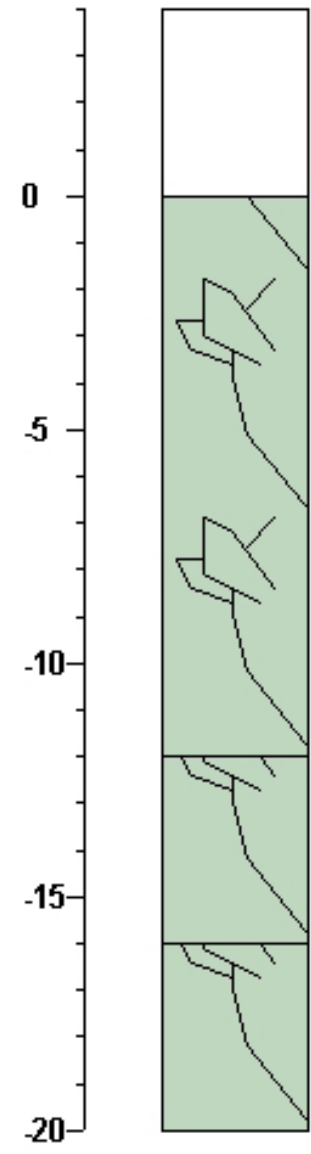

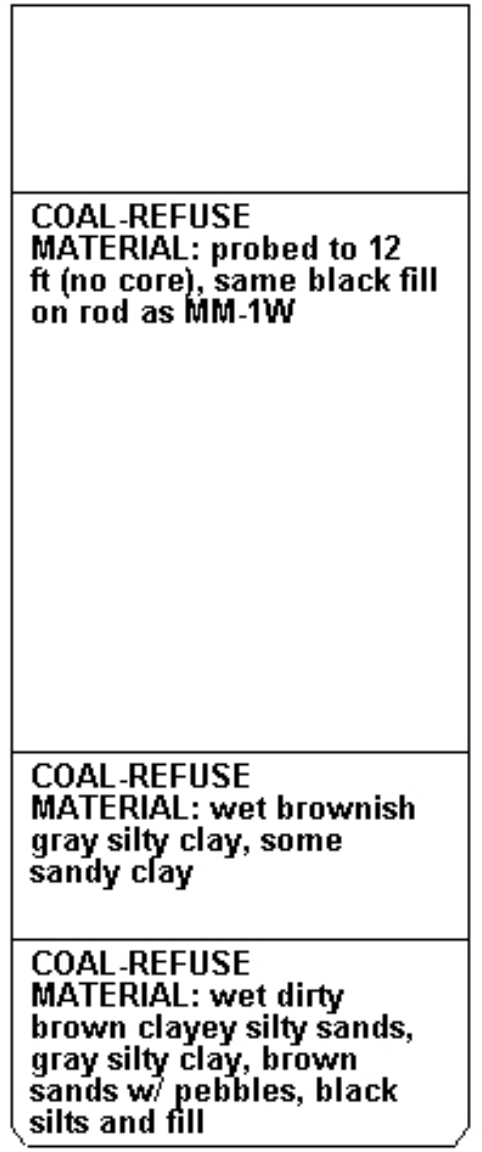

PVC stickup of 3.1

Bentonite from 0 to $3.0^{\circ}$

Filter pack sand from 3 to 5

Natural fill from 5 to 20

Top of screen at 14.8

Bottom of screen at 19.8

Bottom of borehole at 20 
₹USGS

\section{Geologic Boring and Construction Log}

Project: MWRD

LOCATION: Morgan Mine

Well ID MM-3W

METHOD : Geoprobe

DATE : $\quad 9-22-06$

\begin{tabular}{l|l|l|l|l}
$\begin{array}{l}\text { Depth } \\
\text { (feet) }\end{array}$ & $\begin{array}{l}\text { Geologic } \\
\log \end{array}$ & Geologic description & $\begin{array}{l}\text { Well } \\
\text { construction }\end{array}$ & $\begin{array}{l}\text { Well description } \\
\text { (feet) }\end{array}$
\end{tabular}
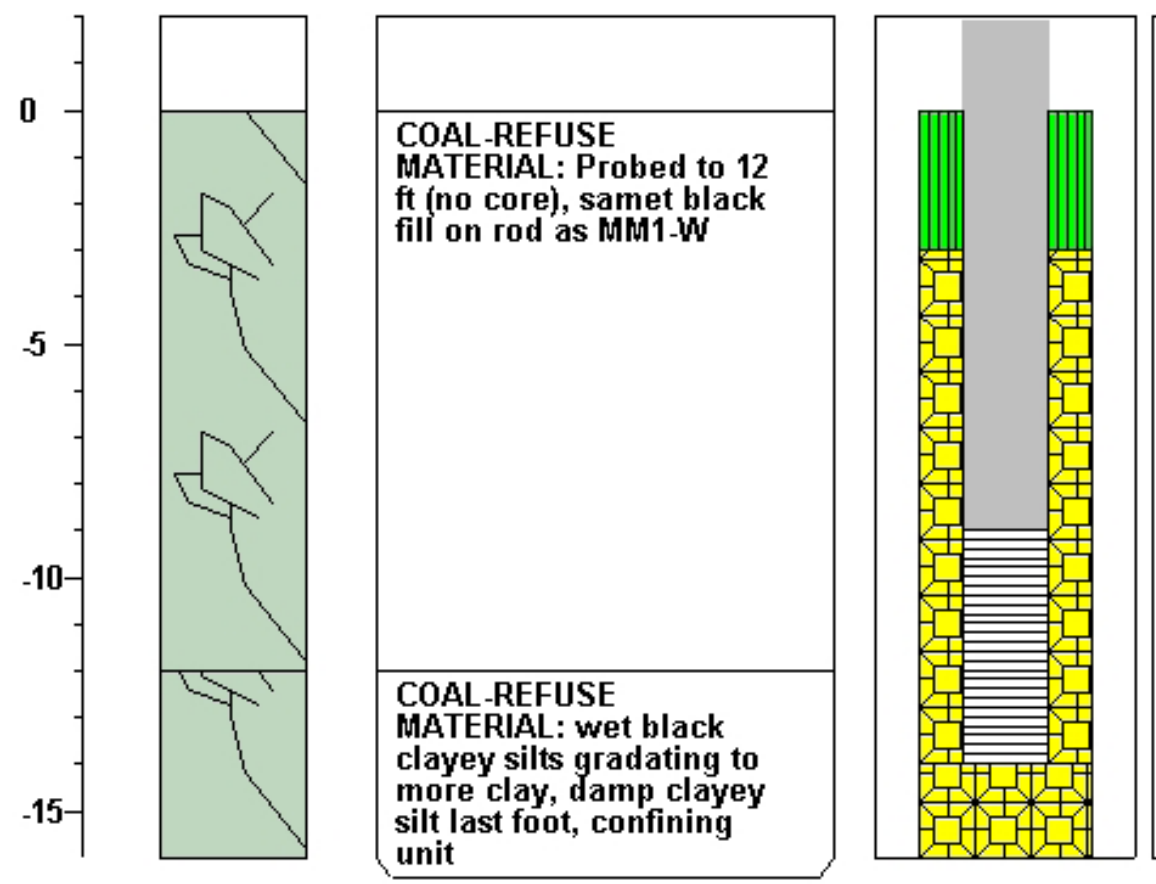

PVC stickup of 1.9

Bentonite from 0 to 3.0

Filter pack sand from at least 3 to 5 , then filter pack sand and natural fili from 5 to 16

Top of screen at 9.0

Bottom of screen at 14.0

Bottom of borehole at 16 


\section{Geologic Boring and Construction Log}

Project: MWRD

LOCAT ION : St. David

$\begin{array}{ll}\text { Well ID } & \text { SD-1W } \\ \text { METHOD: } & \text { Geoprobe } \\ \text { DATE : } & 9-18-06\end{array}$

\begin{tabular}{l|l|l|l|l}
$\begin{array}{l}\text { Depth } \\
\text { (feet) }\end{array}$ & Geologic & Geologic description & $\begin{array}{l}\text { Well } \\
\text { construction }\end{array}$ & $\begin{array}{l}\text { Well description } \\
\text { (feet) }\end{array}$
\end{tabular}

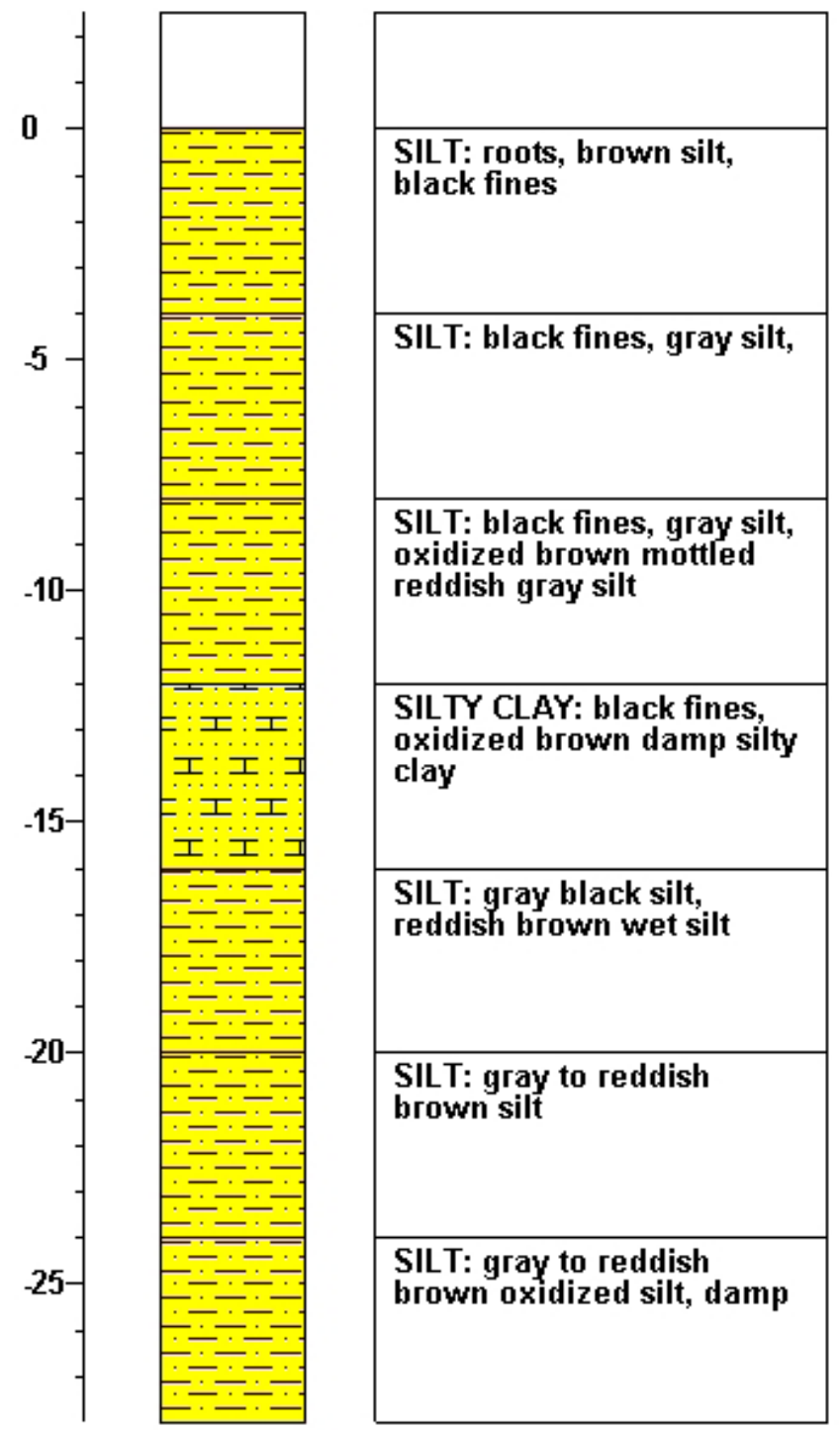

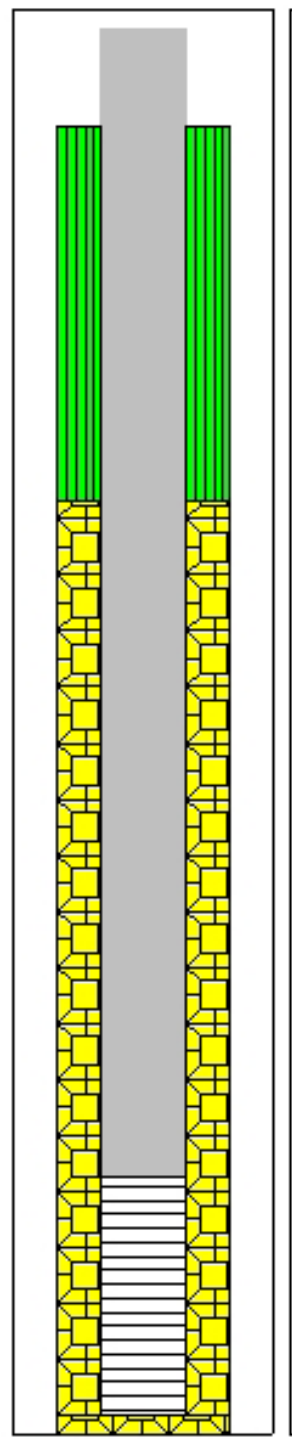

PVC stickup of 2.1

Bentonite from 0 to 8

Filter pack and natural fill from 8-28

Top of screen at 22.6

Bottom of screen at 27.6

Bottom of borehole at 28 
₹USGS

\section{Geologic Boring and Construction Log}

Project: MWRD

LOCATION: Saint David

Well ID SD-2W

METHOD : Geoprobe

DATE : $\quad 9-18-06$

\begin{tabular}{l|l|l|l|l}
$\begin{array}{l}\text { Depth } \\
\text { (feet) }\end{array}$ & $\begin{array}{l}\text { Geologic } \\
\text { log }\end{array}$ & Geologic description & $\begin{array}{l}\text { Well } \\
\text { construction }\end{array}$ & $\begin{array}{l}\text { Well description } \\
\text { (feet) }\end{array}$
\end{tabular}

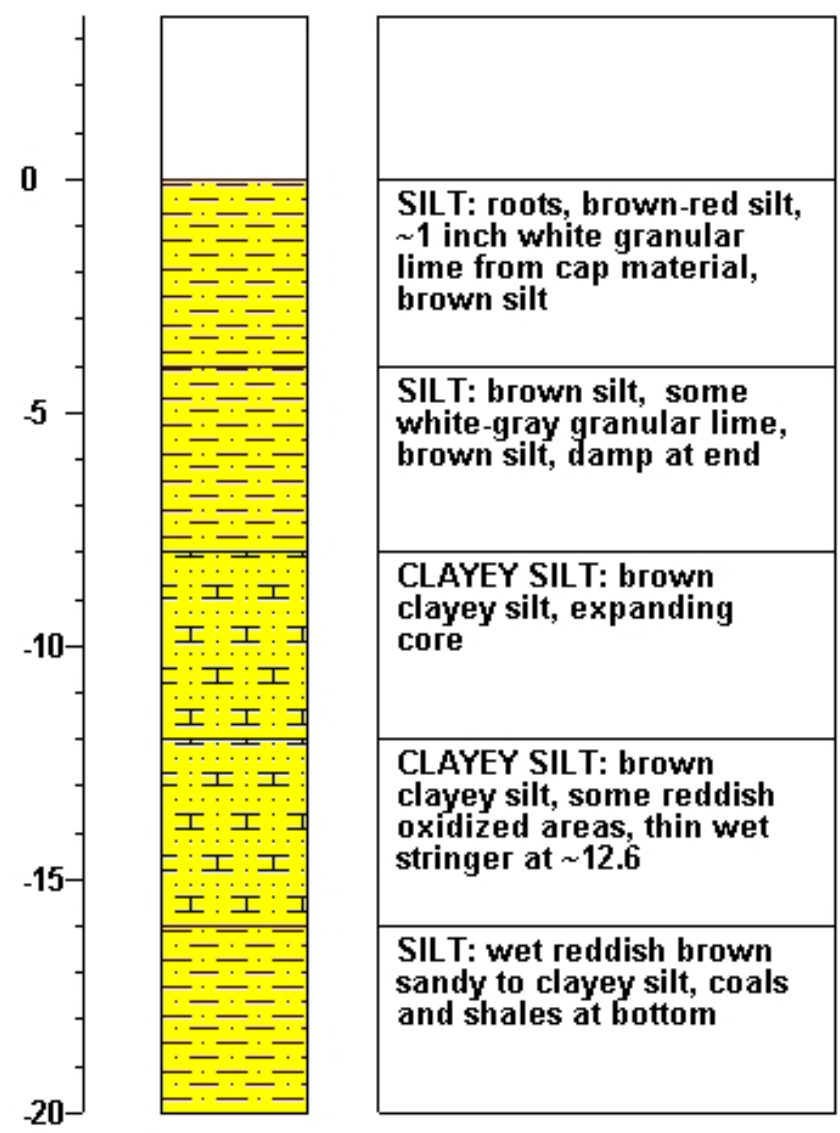

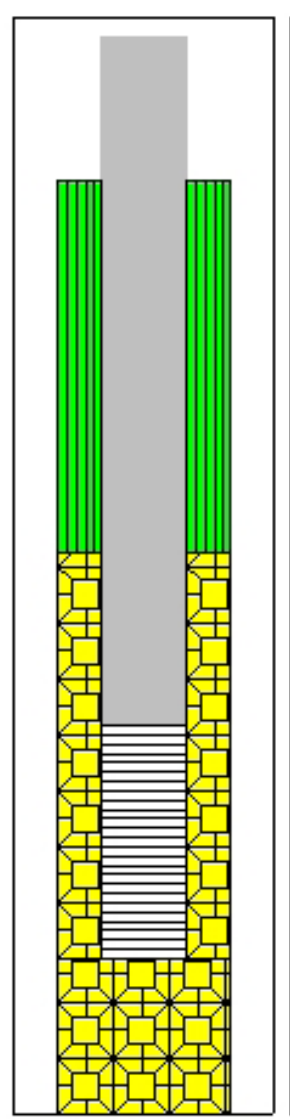

PVC stick up at 3.05

Bentonite from 0 to 8

Filter pack and natural fill from 8 to 20

Top of screen at 11.7

Bottom of screen at 16.7

Bottom of borehole at 20 
Project: MWRD

LOCAT ION : st. David

Well ID SD-3W

METHOD: Geoprobe

DATE : $\quad 9-19-06$

\begin{tabular}{l|l|l|l|l}
$\begin{array}{l}\text { Depth } \\
\text { (feet) }\end{array}$ & $\begin{array}{l}\text { Geologic } \\
\log \end{array}$ & Geologic description & $\begin{array}{l}\text { Well } \\
\text { construction }\end{array}$ & $\begin{array}{l}\text { Well description } \\
\text { (feet) }\end{array}$
\end{tabular}

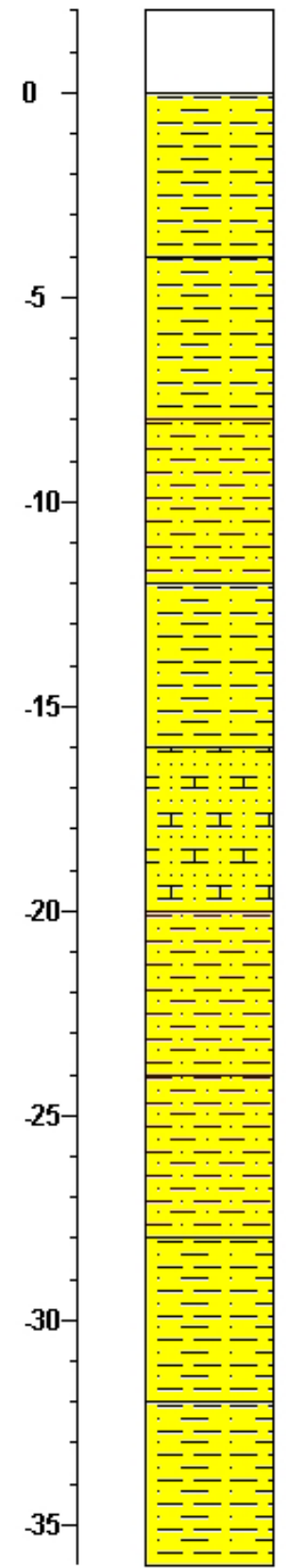

\begin{tabular}{|l|}
\hline \\
\hline $\begin{array}{l}\text { SILT WITH SHALE FINES: } \\
\text { organics, black shale } \\
\text { fines with silt }\end{array}$ \\
\hline $\begin{array}{l}\text { SILT WITH SHALE FINES: } \\
\text { black silt with shale and } \\
\text { coal fines }\end{array}$ \\
\hline $\begin{array}{l}\text { SILT: black silt with } \\
\text { reworked refuse pile } \\
\text { material }\end{array}$ \\
\hline $\begin{array}{l}\text { SILT WITH SHALE FINES: } \\
\text { black silt with shale refuse } \\
\text { fines }\end{array}$ \\
\hline $\begin{array}{l}\text { SILT WITH SHALE FINES: } \\
\text { coal, then gray reworked } \\
\text { silty-shales }\end{array}$ \\
\hline $\begin{array}{l}\text { SILT: black gray silt, dry } \\
\text { lo silty-sand size. brown } \\
\text { silt }\end{array}$ \\
\hline $\begin{array}{l}\text { SILT WITH SHALE FINES: } \\
\text { black gray silt to brown } \\
\text { silt, black reworked coals } \\
\text { and shales } \\
\text { clayey silt }\end{array}$ \\
\hline $\begin{array}{l}\text { SILT: brown silt, coal } \\
\text { chunks at base? }\end{array}$ \\
\hline
\end{tabular}

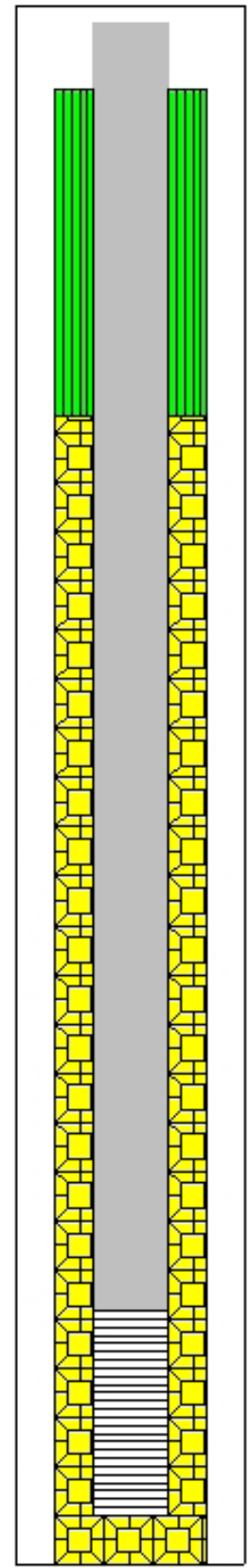

PVC stickup of 1.6

Bentonite from 0 to 8

Filter pack and natural fill from 8 to 36

Top of screen at 29.8

Bottom of screen at $\mathbf{3 4 . 8}$ 


\section{Geologic Boring and Construction Log}

\author{
Project: MWRD \\ LOCATION : Saint David \\ Well ID SD-4W \\ METHOD : Geoprobe \\ DATE : $\quad 9-27-06$
}

\section{\begin{tabular}{l|l|l|l|l}
$\begin{array}{l}\text { Depth } \\
\text { (feet) }\end{array}$ & Geologic & Geologic description & $\begin{array}{l}\text { Well } \\
\text { construction }\end{array}$ & $\begin{array}{l}\text { Well description } \\
\text { (feet) }\end{array}$
\end{tabular}}

\begin{tabular}{|l|l|}
\hline & $\begin{array}{l}\text { TOPSOIL: Roots, soil, } \\
\text { organics with coal tailings } \\
\text { mixed with organics }\end{array}$ \\
\hline $\begin{array}{l}\text { SILTY SAND: loose } \\
\text { unconsolidated coal } \\
\text { tailings and brown red } \\
\text { loose silty/sandy soil }\end{array}$ \\
\hline $\begin{array}{l}\text { SILT WITH SHALE FINES: } \\
\text { black to gray coal shale } \\
\text { tailings, silt to clay } \\
\text { sized/dry, black clayey } \\
\text { sand coal fill, wet. }\end{array}$ \\
\hline $\begin{array}{l}\text { SILT WITH SHALE FINES: } \\
\text { wet black } \\
\text { sandy/silty/clayey coal } \\
\text { tailings }\end{array}$ \\
\hline $\begin{array}{l}\text { COAL-REFUSE } \\
\text { MATERIAL: wet } \\
\text { silty/sandy sized black } \\
\text { coal and shale mixture }\end{array}$ \\
\hline $\begin{array}{l}\text { COAL-REFUSE } \\
\text { MATERIAL: black soupy } \\
\text { coal tailings fill mixture }\end{array}$ \\
\hline $\begin{array}{l}\text { COAL-REFUSE } \\
\text { MATERIAL: black sandy } \\
\text { coal fill, coal seam at end } \\
\text { of core tube, coal } \\
\text { bedrock. refusal at } 25\end{array}$ \\
\hline
\end{tabular}

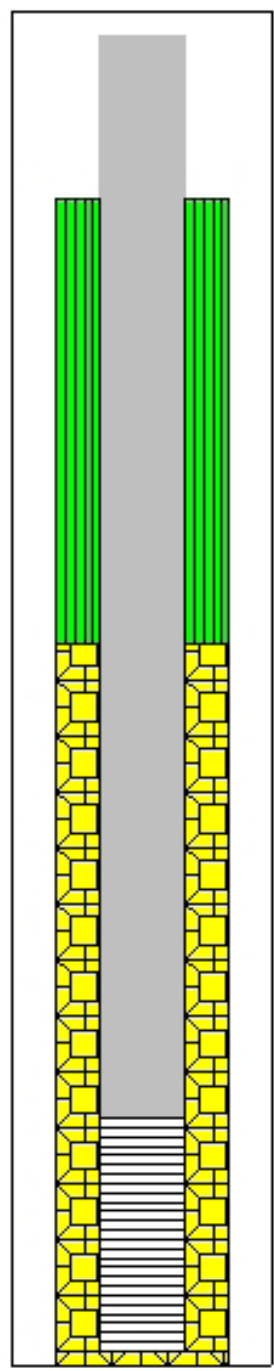

PVC stickup of 3.5

Bentonite from 0 to 9.5

Filter pack and natural fill from 9.5 to 25

Top of screen at 19.7

Bottom of screen at 24.7

Bottom of borehole at 25 


\section{ॠUSGS Geologic Boring Log}

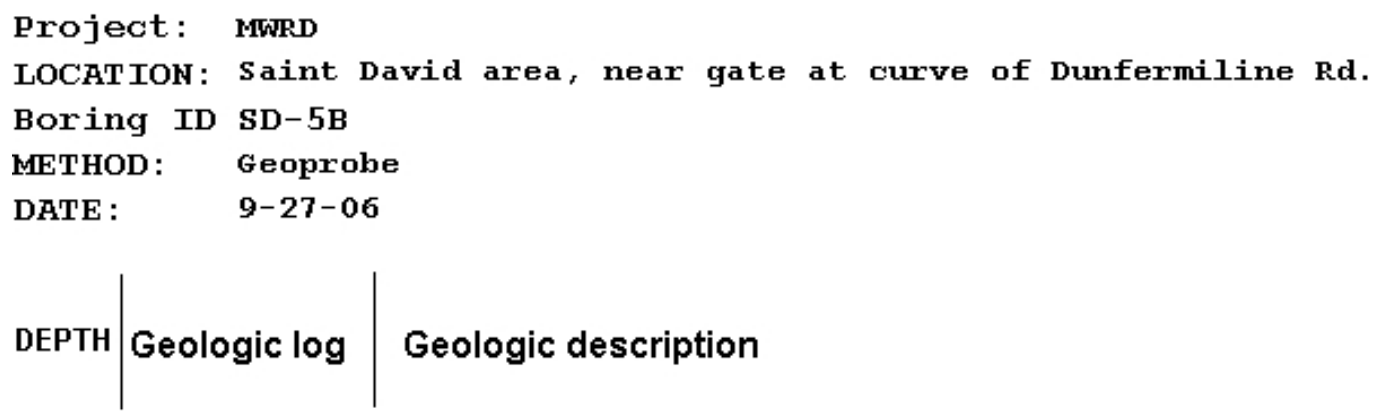

0

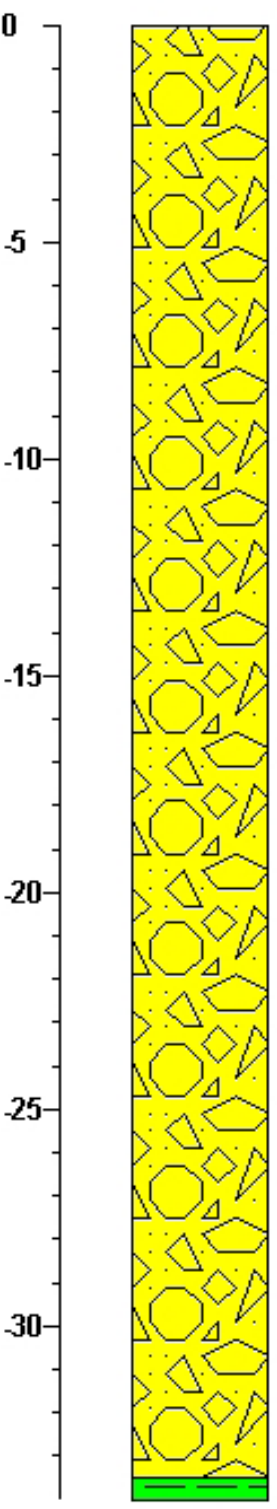

TILL: Preprobe through till, easy push to easy hammer to 32 , then moderate to hard

hammering from 32 to 33.5

SHALE: Refusal at 33.5.

Gray shale at end of probe tip and electric tape gage at 33.5. Dry hole. 
₹USGS

\section{Geologic Boring and Construction Log}

Project: MWRD

LOCATION : UEC

Well ID UEC-1W

METHOD : Geoprobe

DATE : 9-19-06

\begin{tabular}{l|l|l|l|l}
$\begin{array}{l}\text { Depth } \\
\text { (feet) }\end{array}$ & $\begin{array}{l}\text { Geologic } \\
\log \end{array}$ & Geologic description & $\begin{array}{l}\text { Well } \\
\text { construction }\end{array}$ & $\begin{array}{l}\text { Well description } \\
\text { (feet) }\end{array}$
\end{tabular}

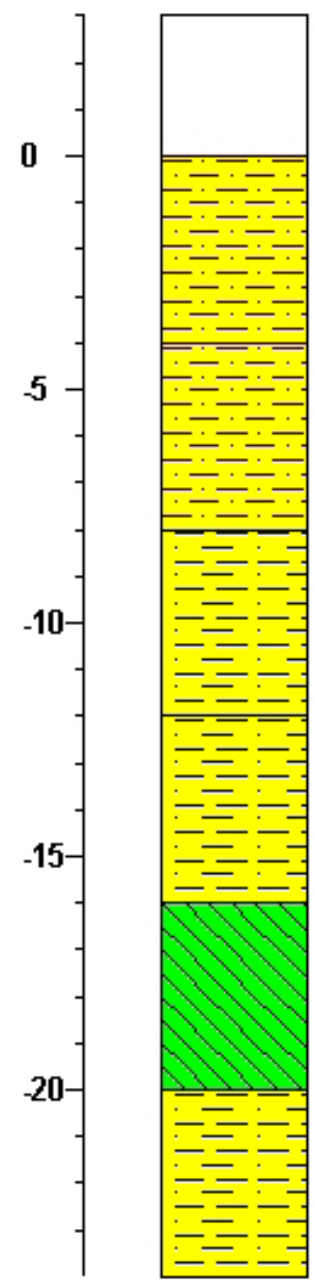

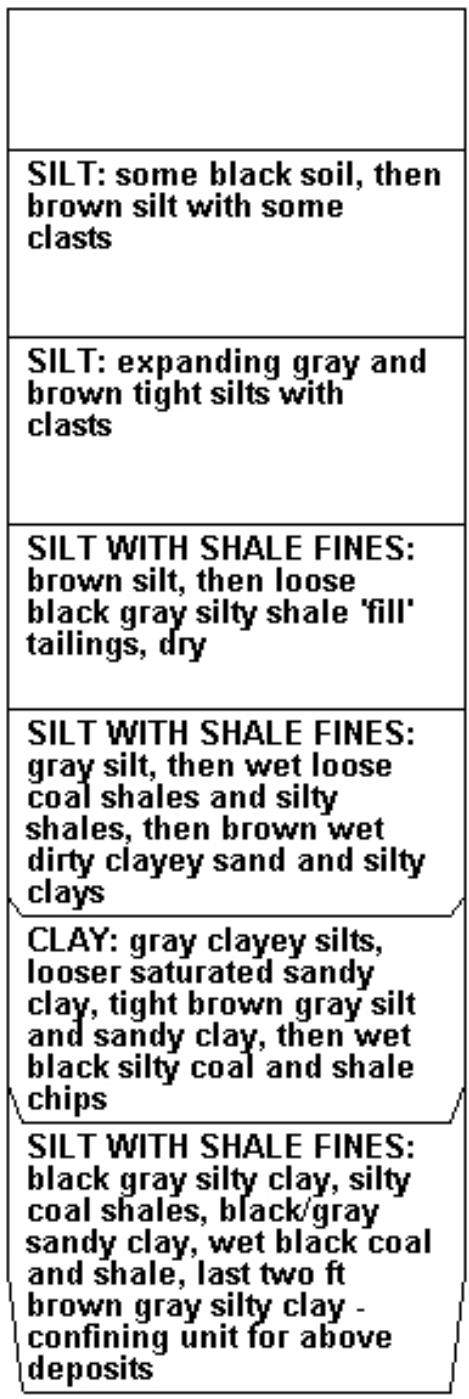

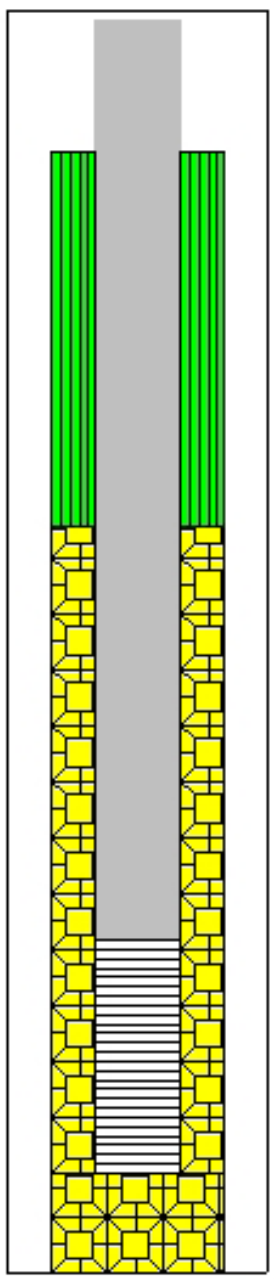

PVC stickup of 2.8

Bentonite from 0 to 8.0

Filter pack sand and natural fill, from 8 to 24 , all filter pack sand from $\sim 8$ to 10 .

Top of screen at $\mathbf{1 6 . 9}$

Bottom of screen at 21.9

Bottom of borehole at 24 
Project: MWRD

LOCAT ION : UEC

Well ID UEC-2W

METHOD: Geoprobe

DATE : $\quad$ 9-20-06

\begin{tabular}{l|l|l|l|l}
$\begin{array}{l}\text { Depth } \\
\text { (feet) }\end{array}$ & $\begin{array}{l}\text { Geologic } \\
\log \end{array}$ & Geologic description & $\begin{array}{l}\text { Well } \\
\text { construction }\end{array}$ & $\begin{array}{l}\text { Well description } \\
\text { (feet) }\end{array}$
\end{tabular}

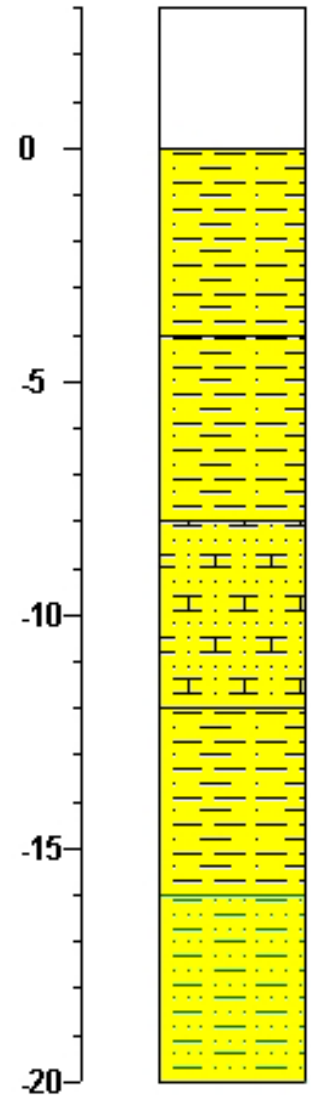

\begin{tabular}{|l|}
\hline \\
\hline $\begin{array}{l}\text { SILT WITH SHALE FINES: } \\
\text { some organic, then brown } \\
\text { silt, then black gray coal } \\
\text { and shale fill }\end{array}$ \\
\hline $\begin{array}{l}\text { SILT WITH SHALE FINES: } \\
\text { brown silt, black-gray coal } \\
\text { shale fines w/ pebbles, } \\
\text { tight brown clayey silt }\end{array}$ \\
\hline $\begin{array}{l}\text { CLAYEY SILT: brown silt } \\
\text { w/ black shales, brown } \\
\text { powdery silt "sugar sand", } \\
\text { then very tight light brown } \\
\text { clayey silt }\end{array}$ \\
\hline $\begin{array}{l}\text { SILT WITH SHALE FINES: } \\
\text { wet clayey silts with black } \\
\text { coal and shale pieces, } \\
\text { tight brown silt }\end{array}$ \\
\hline $\begin{array}{l}\text { CLAYEY SAND: brown silt, } \\
\text { then six inches of brown } \\
\text { soupy clayey sands, then } \\
\text { tight brown clayey silt }\end{array}$ \\
\hline
\end{tabular}

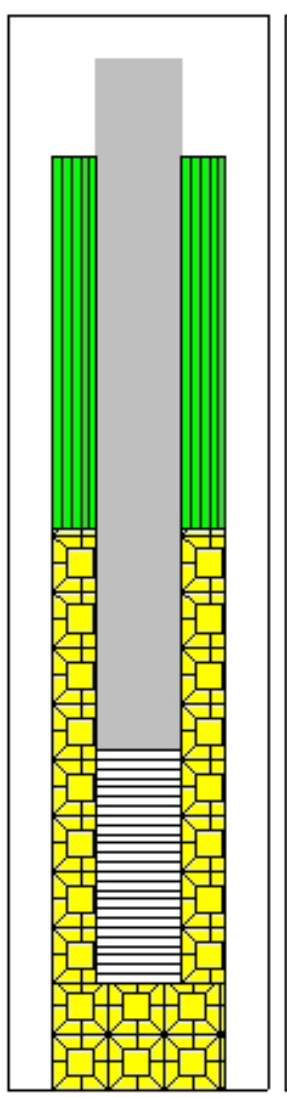

PVC stickup of 2.1

Bentonite from 0 to 8

Filter pack sand and natural fill from 8 to 20

Top of screen at 12.7

Bottom of screen at 17.7

Bottom of borehole at 20 


\section{Geologic Boring and Construction Log}

Project: MWRD

LOCAT ION : UEC
Well ID
UEC-3W
METHOD :
Geoprobe
DATE :
9-20-06

\begin{tabular}{l|l|l}
$\begin{array}{l}\text { Depth } \\
\text { (feet) }\end{array}$ & Geologic & Geologic description
\end{tabular}

\begin{tabular}{|l|l} 
Well & Well description \\
construction & $\begin{array}{l}\text { (feet) } \\
\text { (fen }\end{array}$
\end{tabular}

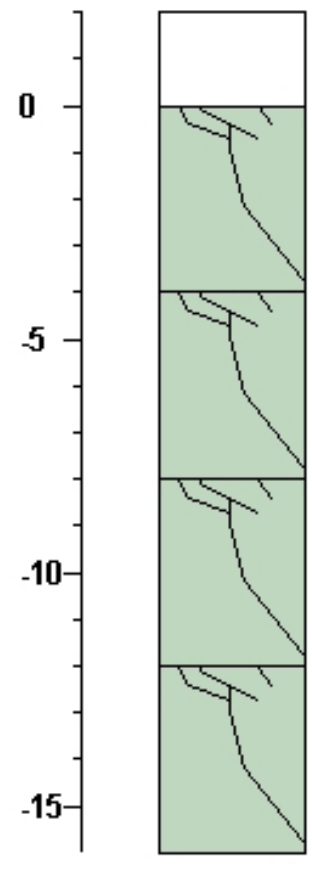

\begin{tabular}{|l|}
\hline \\
\hline $\begin{array}{l}\text { COAL-REFUSE } \\
\text { MATERIAL: yellow silty } \\
\text { clay, then dirty } \\
\text { black'brown'red silt and } \\
\text { shale tailings, some wood } \\
\text { fragments }\end{array}$ \\
\hline $\begin{array}{l}\text { COAL-REFUSE } \\
\text { MATERIAL: tailings fill, } \\
\text { wood, coal fines, brown } \\
\text { silt with pebble clasts }\end{array}$ \\
\hline $\begin{array}{l}\text { COAL-REFUSE } \\
\text { MATERIAL: black coal and } \\
\text { shale fill, black/gray dirty } \\
\text { silts w/ pebble clasts, diry } \\
\text { mottled red/gray oxidized } \\
\text { clayey silts }\end{array}$ \\
\hline $\begin{array}{l}\text { COAL-REFUSE } \\
\text { MATERIAL: wet dark } \\
\text { brown, mottled oxidizing } \\
\text { red, dirty clayey sands } \\
\text { and gravels first .3', then } \\
\text { last 3.7' light gray brown } \\
\text { shales, last foot extremely } \\
\text { tight in shale }\end{array}$ \\
\hline
\end{tabular}

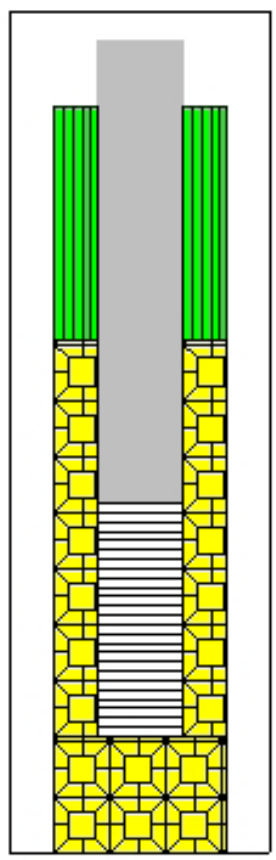

PVC stickup of 1.4

Bentonite from 0 to $5.0^{\circ}$

Filter pack sand and natural fill from 5 to 16 , last couple feet filter pack sand

Top of screen at 8.5

Bottom of screen at $\mathbf{1 3 . 5}$

Bottom of borehole at 16 


\section{Geologic Boring and Construction Log}

Project: MWRD

LOCAT ION : UEC

$\begin{array}{ll}\text { Well ID } & \text { UEC-4W } \\ \text { METHOD: } & \text { Geoprobe } \\ \text { DATE : } & 9-24-06\end{array}$

\begin{tabular}{l|l|l|l|l}
$\begin{array}{l}\text { Depth } \\
\text { (feet) }\end{array}$ & Geologic & Geologic description & $\begin{array}{l}\text { Well } \\
\text { construction }\end{array}$ & $\begin{array}{l}\text { Well description } \\
\text { (feet) }\end{array}$
\end{tabular}

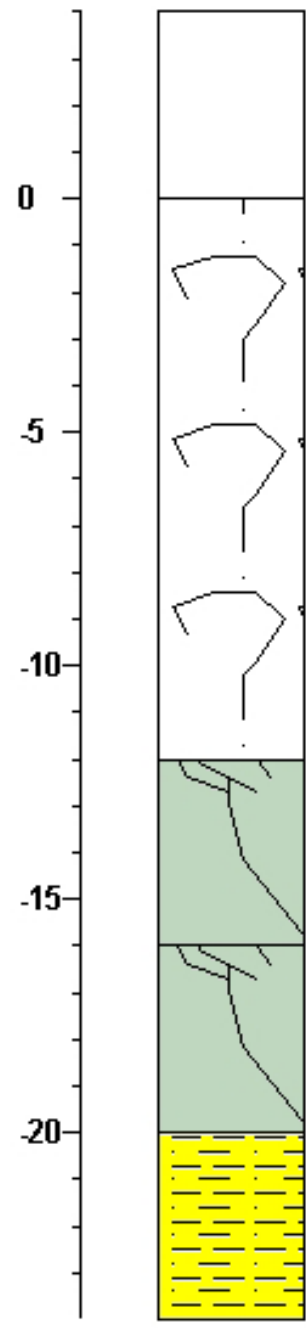

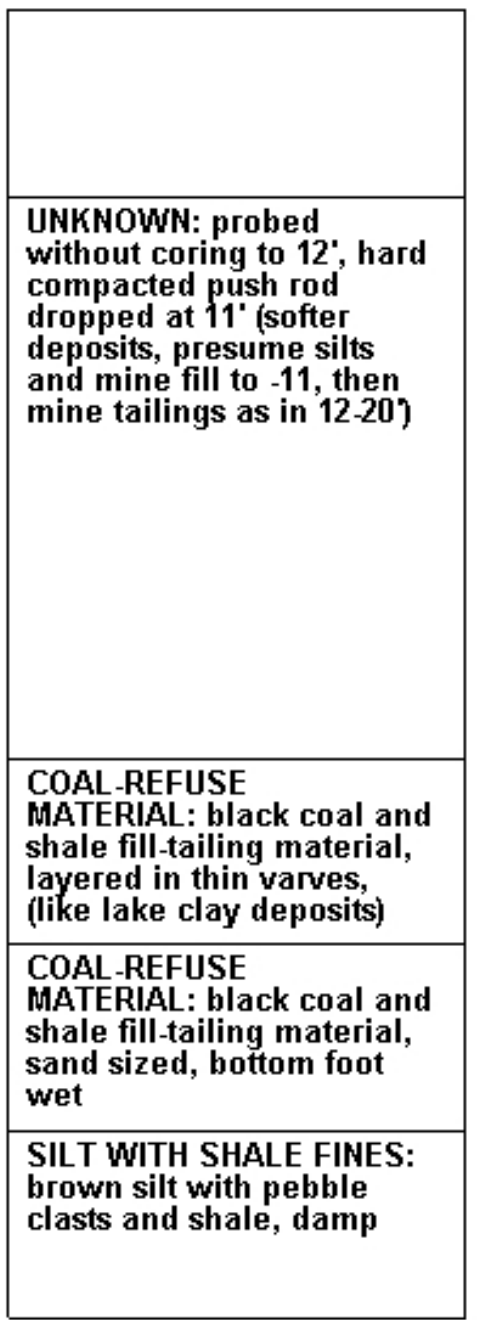

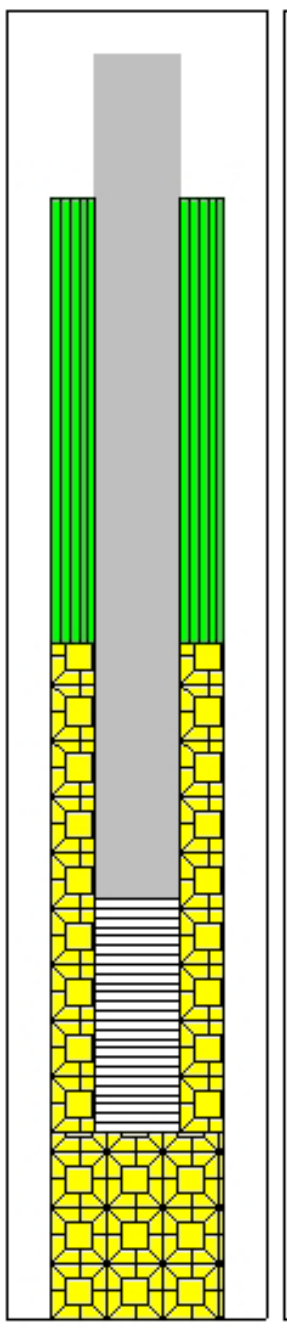

PVC stickup of 3.1

Bentonite from 0 to 9.5

Fine filter pack sand from 9.5 to 10

Coarse filter pack sand from 10 to 14

Natural fill from 14 to 24

Top of screen at $\mathbf{1 5 . 0}$

Bottom of screen at 20

Bottom of borehole at 24 
ఇUSGS

\section{Geologic Boring and Construction Log}

Project: MWPD

LOCATION : UEC

$\begin{array}{ll}\text { Well ID } & \text { UEC-5RW } \\ \text { METHOD : } & \text { Geoprobe } \\ \text { DATE : } & 9-28-06\end{array}$

\begin{tabular}{l|l|l|l|l}
$\begin{array}{l}\text { Depth } \\
\text { (feet) }\end{array}$ & $\begin{array}{l}\text { Geologic } \\
\log \end{array}$ & Geologic description & $\begin{array}{l}\text { Well } \\
\text { construction }\end{array}$ & $\begin{array}{l}\text { Well description } \\
\text { (feet) }\end{array}$
\end{tabular}

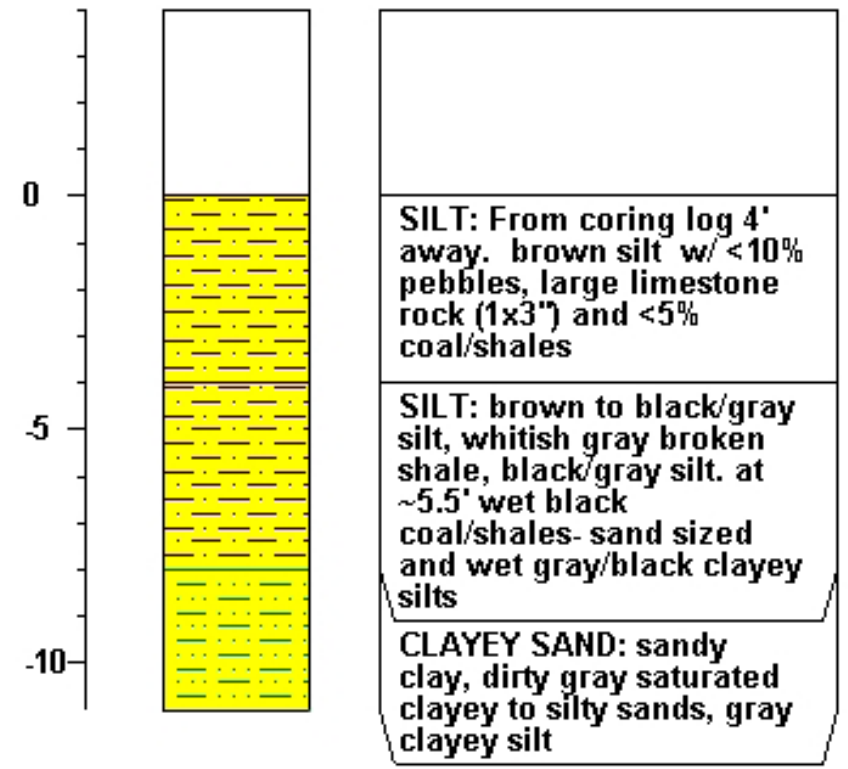

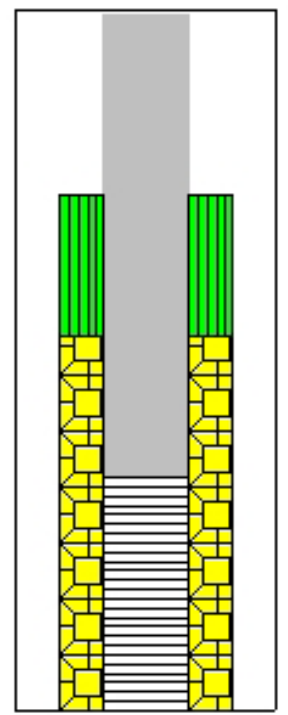

PVC stickup of 3.9

Bentonite from 0 to 3

Filter pack sand and natural fill from 3 to 11

Top of screen at 6.0

Bottom of screen and borehole at 11.0 
Project: MWRD

LOCATION : UEC

Boring ID UEC-6B

METHOD: Geoprobe

DATE : $\quad 9-26-06$

DEPTH $\mid$ Geologic log $\quad$ Geologic description

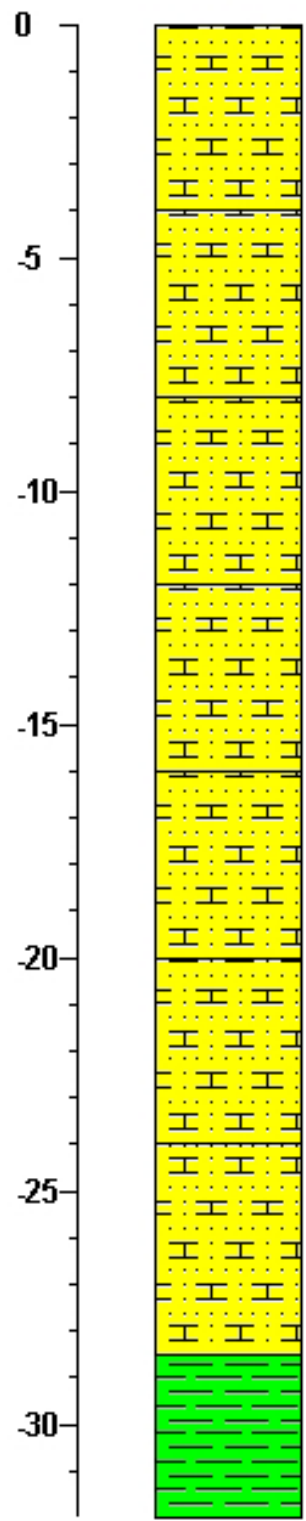

CLAYEY SILT: glacial till -. brown to grayish brown clayey silt

CLAYEY SILT: glacial till -tight brown clayey silt, $<10 \%$ pebbles, 0.5 clayey silt, black coal/shale mottling present with reddish oxidized areas

CLAYEY SILT: glacial till -extremely tight brown clayey silt with occasional black coal shale mottling, some pebbles $(<10 \%)$

CLAYEY SILT: glacial till -first $\sim 1.5^{\prime}$ brown clayey silt, not many pebbles. next $2.5^{\circ}$ - very tight brown clayey silt with $>10 \%$ pebbles, dry, contains sand pebbles, coal fragments, large gravels

CLAYEY SILT: glacial till -tight brown clayey silt

SILTY CLAY: glacial till -very tight brown silty clay mottled with gray silty clay, thin ( 0.3$)$ dry fine weli sorted brown sand at $\sim 22.5^{\prime}$, tight brown silty clay with pebbles gradating to gray clay at bottom (24)

SILTY CLAY: glacial till -extremely tight black/gray silty clay with numerous pebbles and clasts $\sim 10 \%$, turning blacker and shalier at bottom

SHALE: weathered shale from 28.5 to $29^{\prime}$, then hard gray competent shale, $\mathrm{dry}$, refusal at $29^{\circ}$ 
Appendix 2. Constituent Concentration Data in Background Wells from 1999-2006

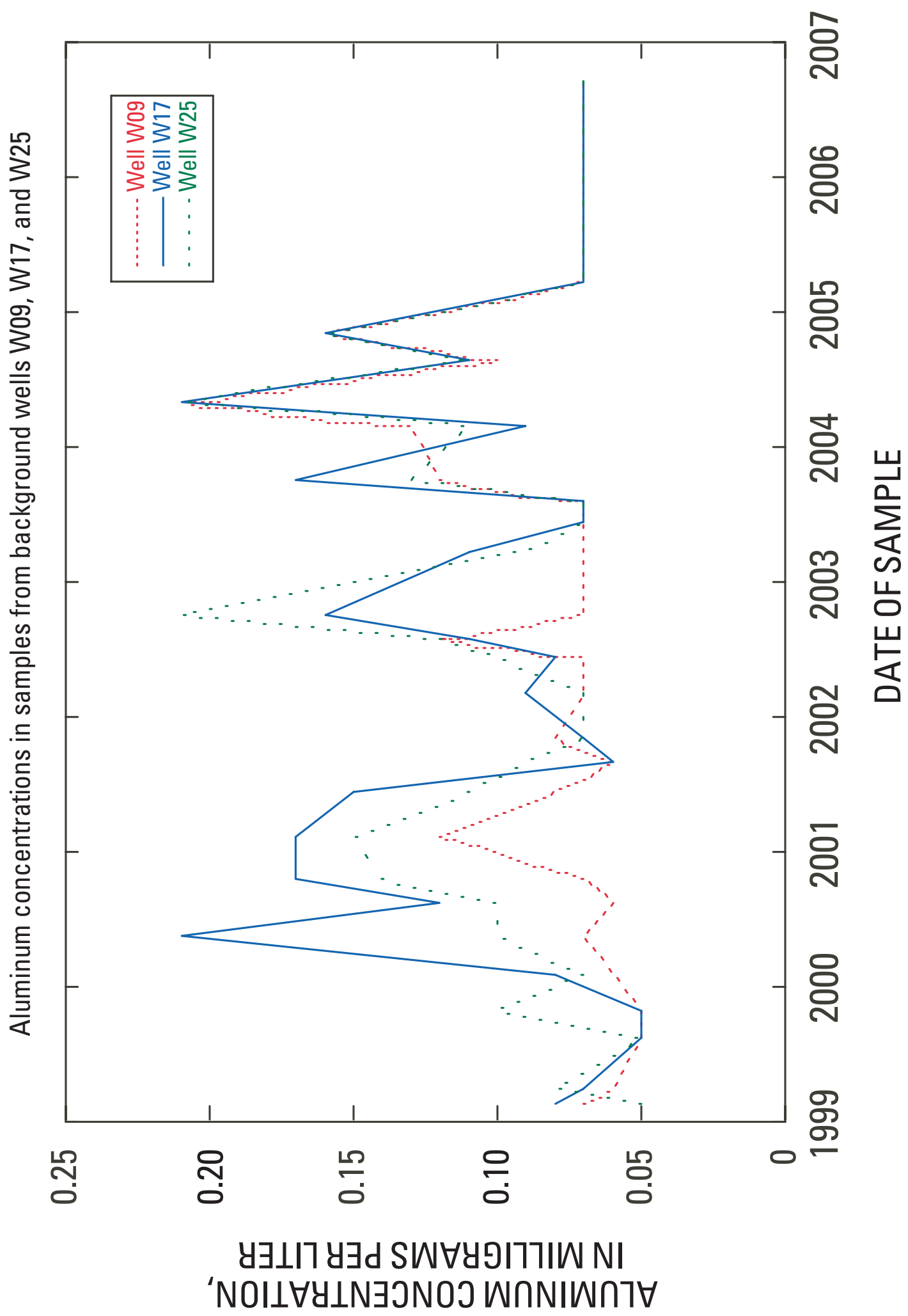




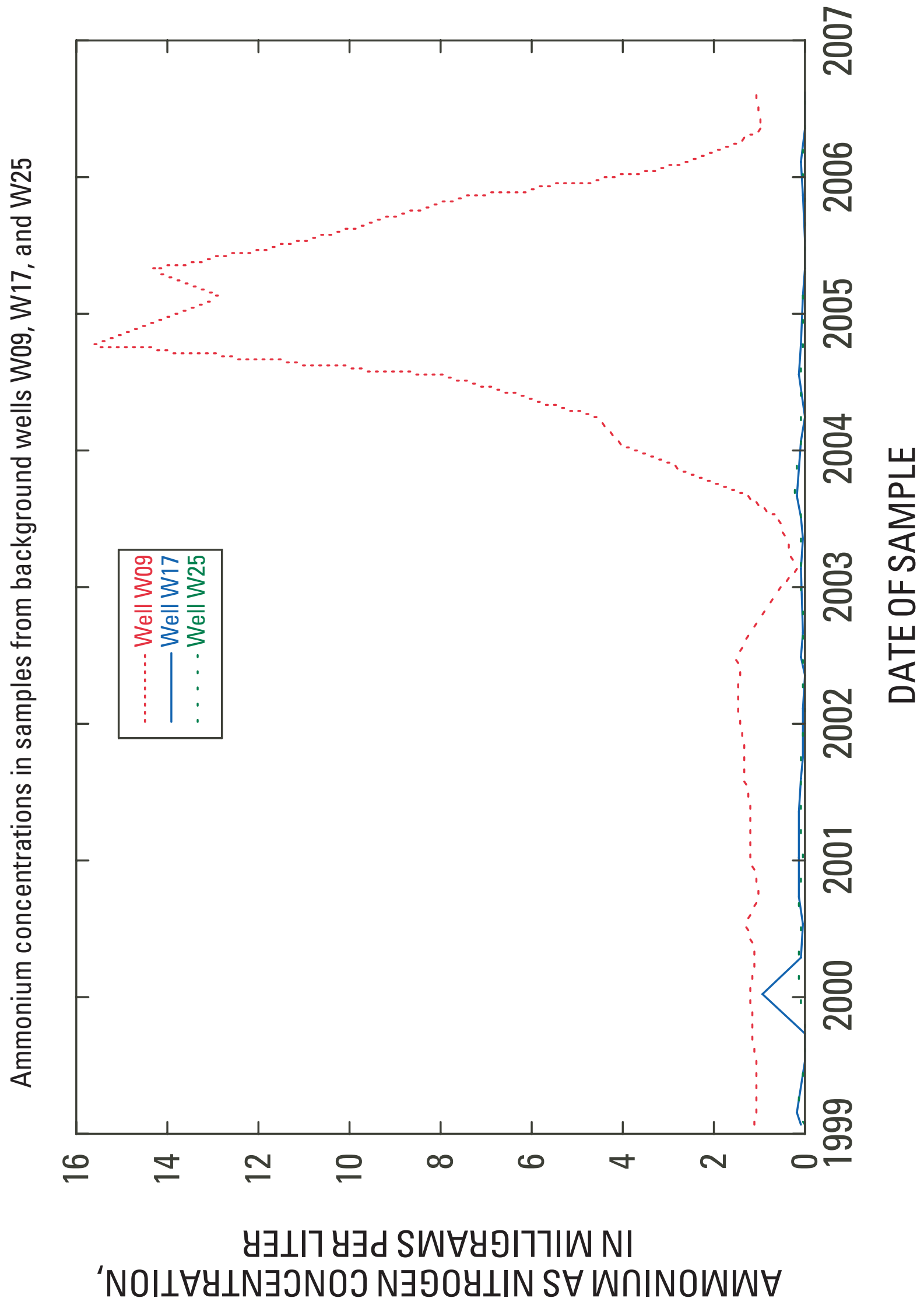




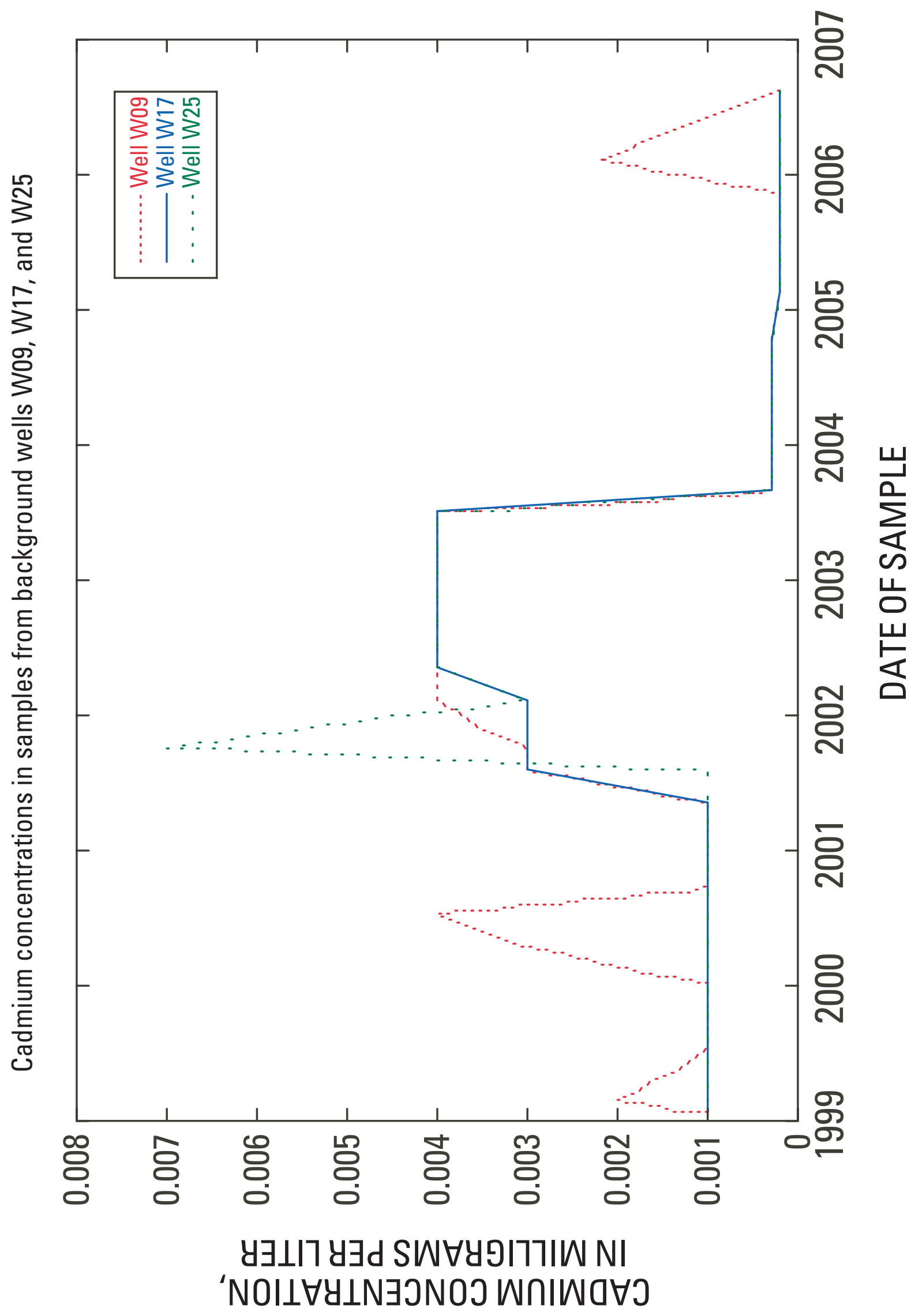




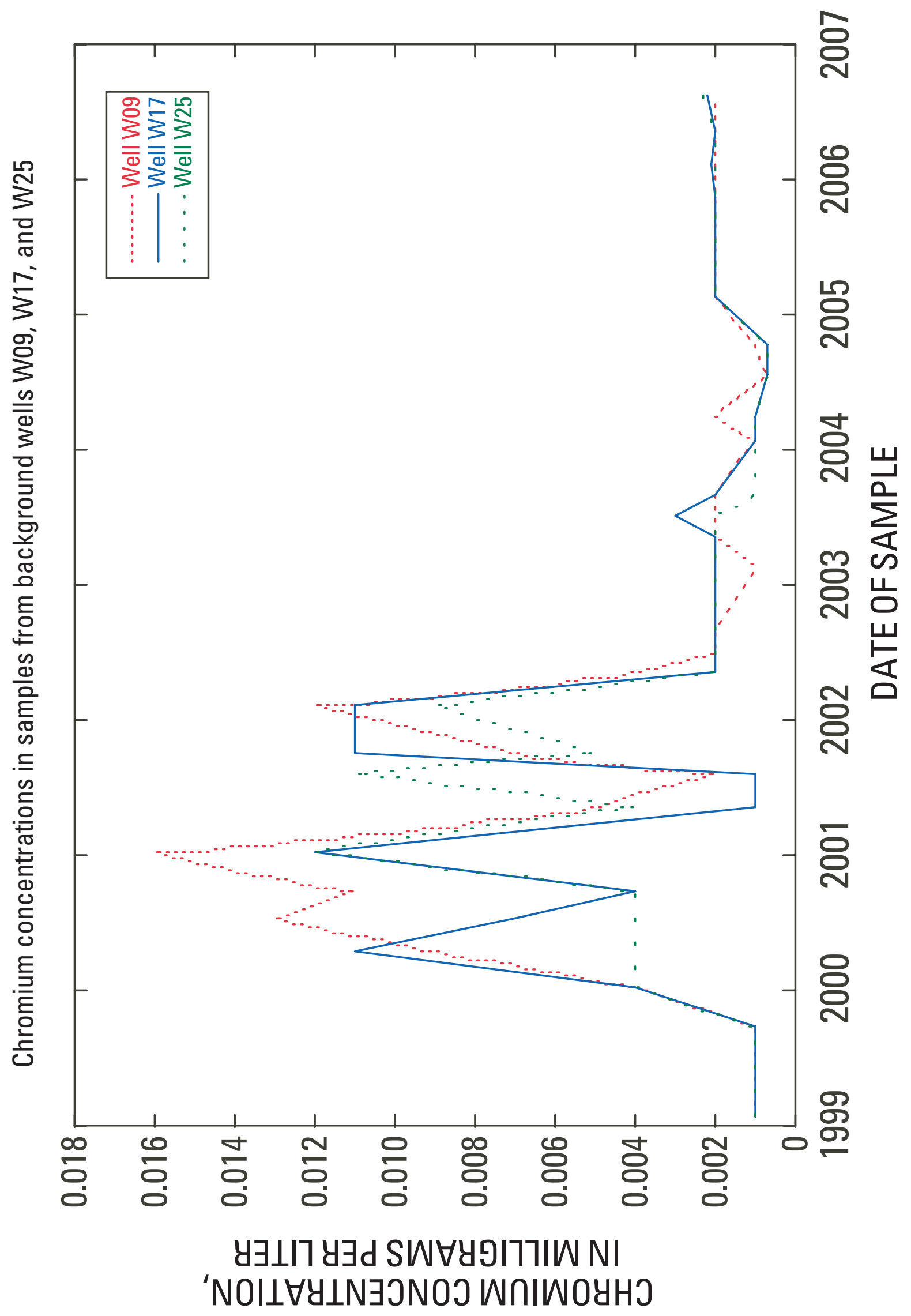




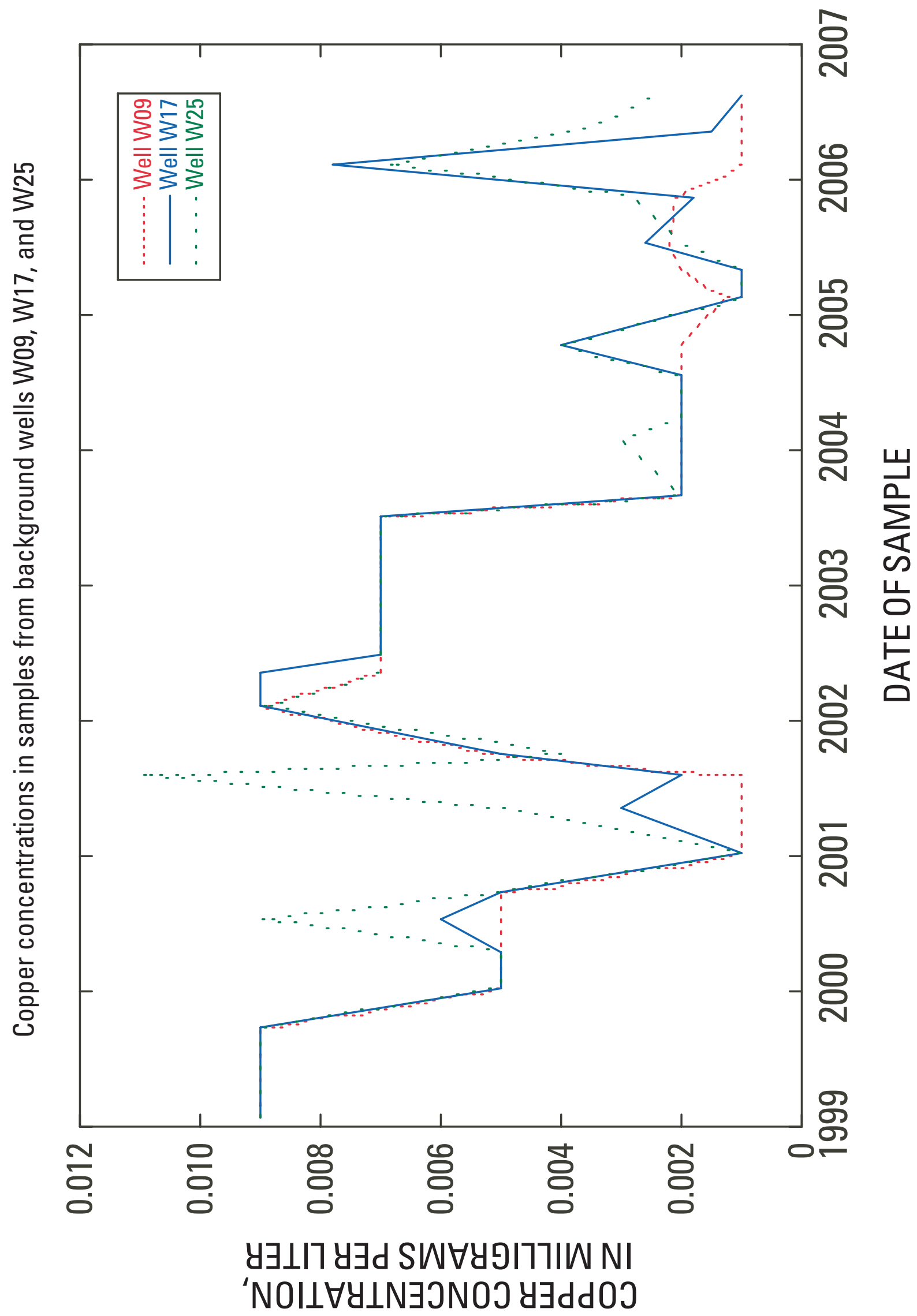




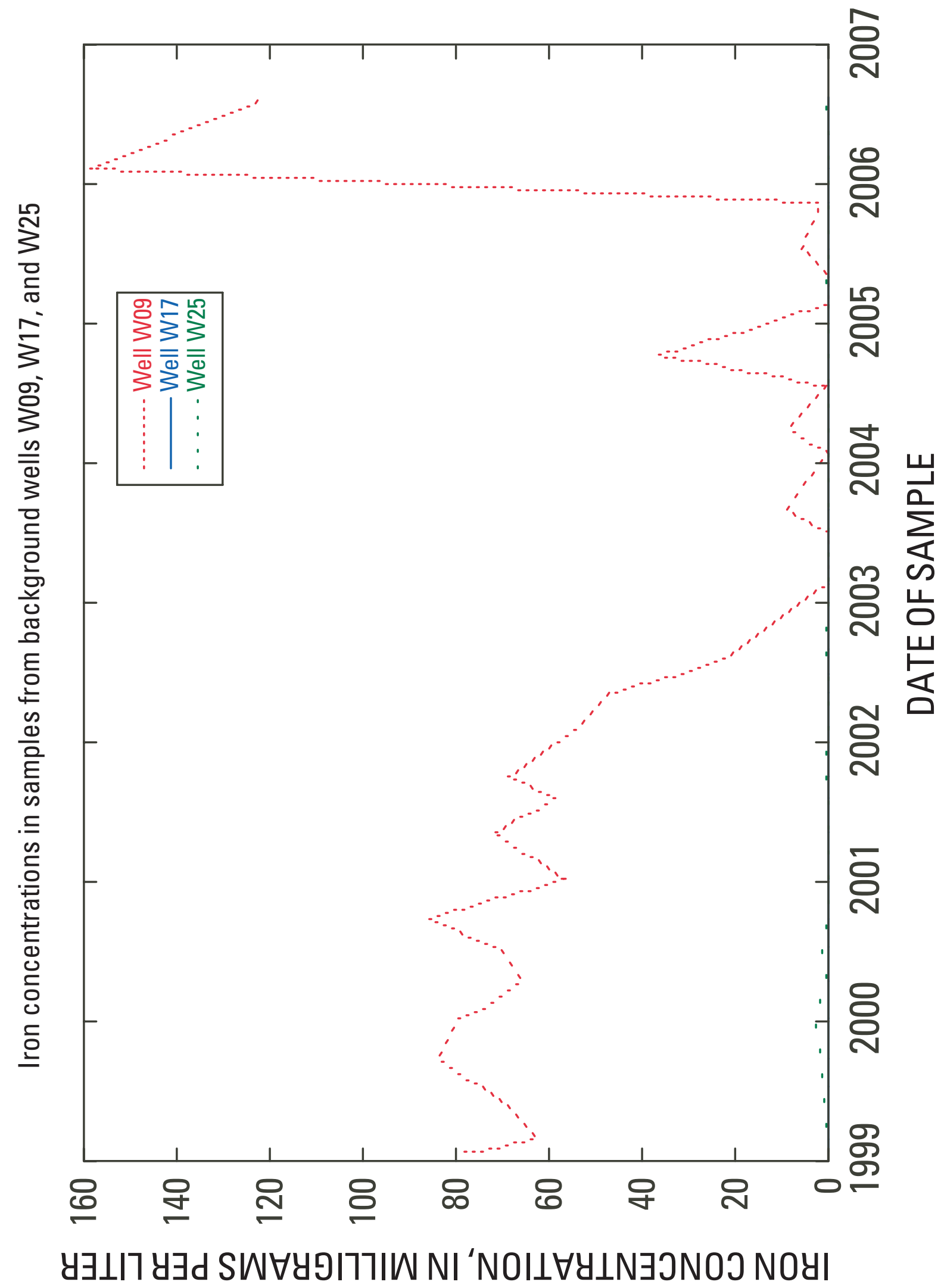




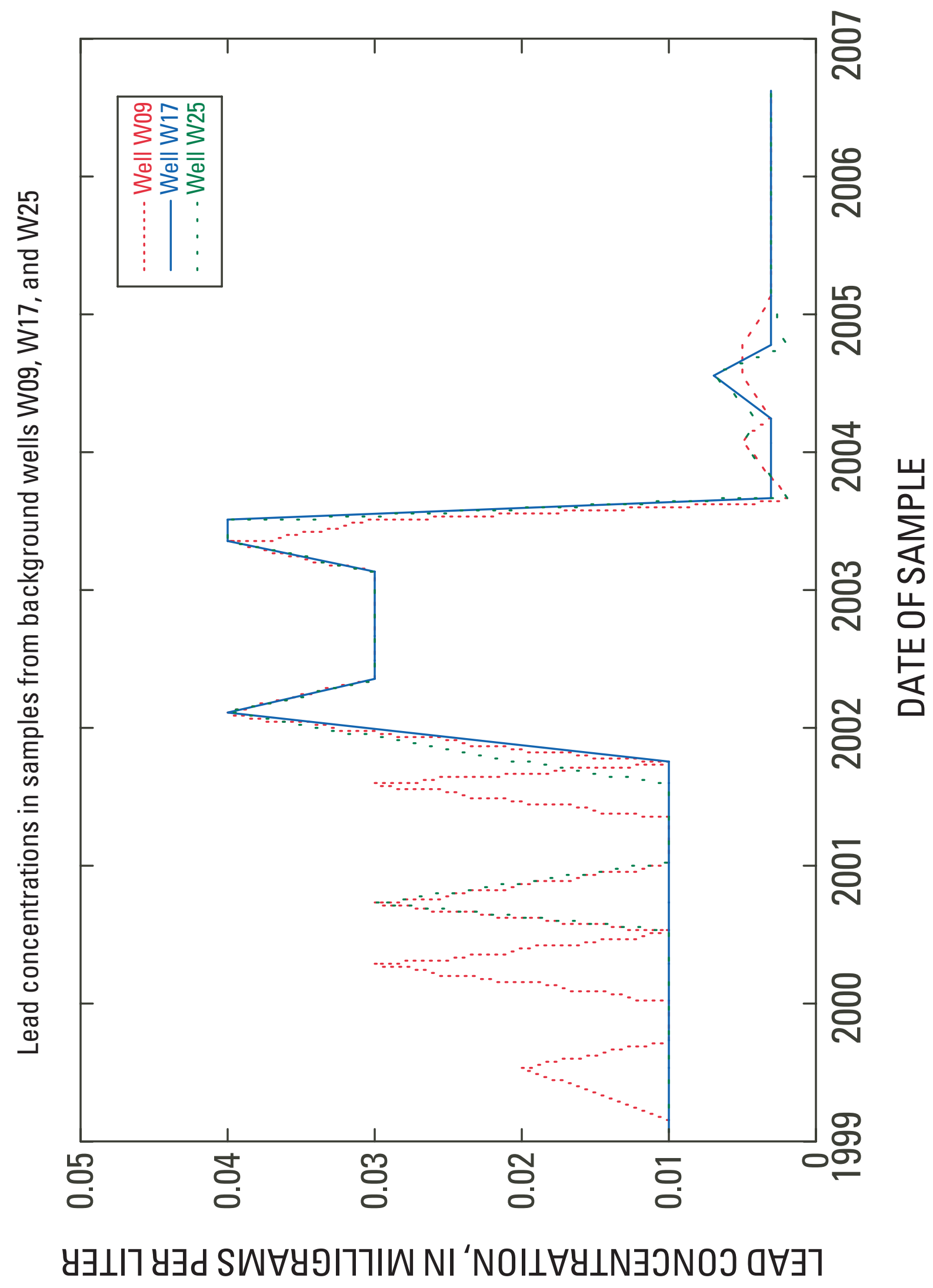




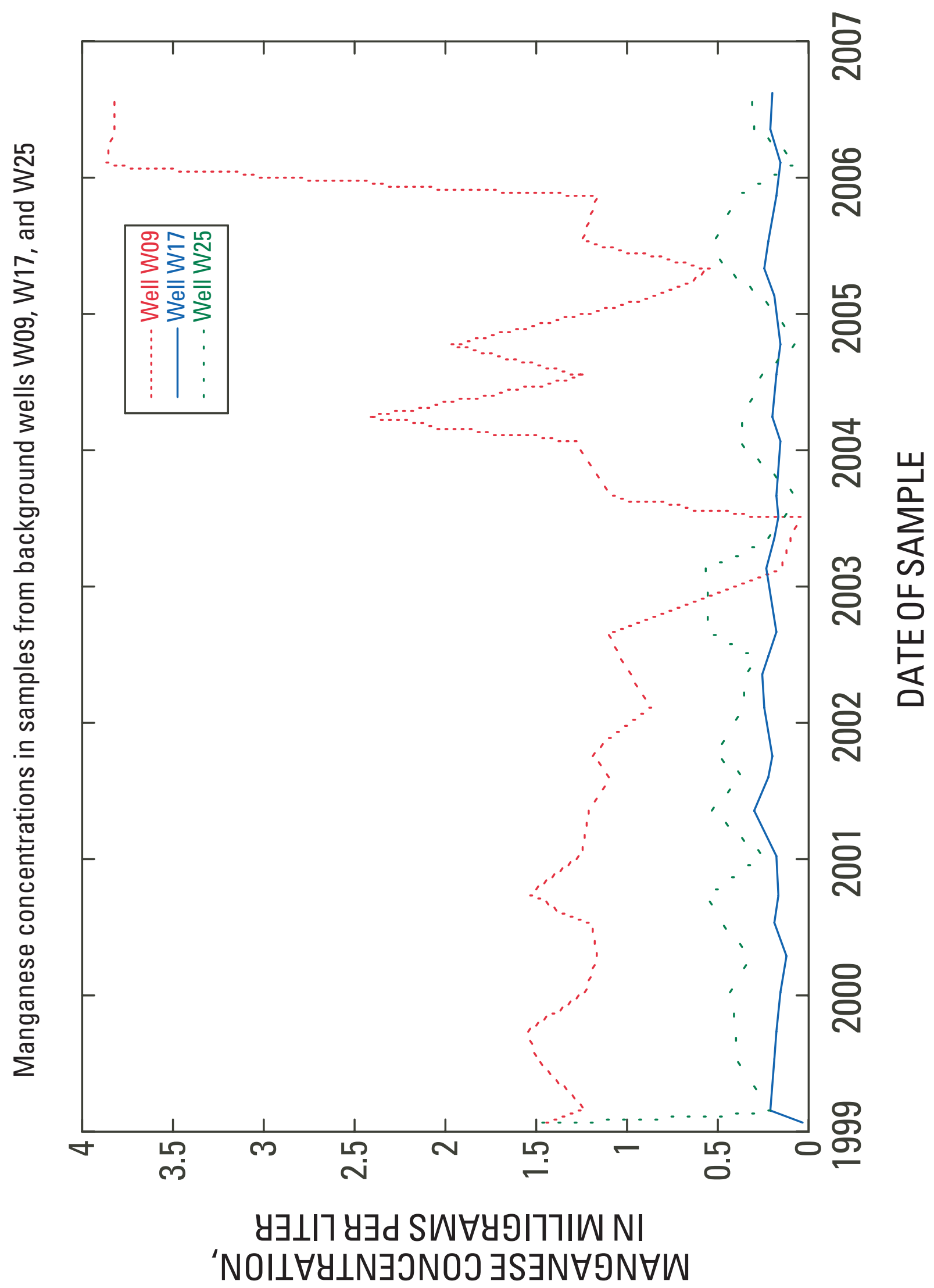




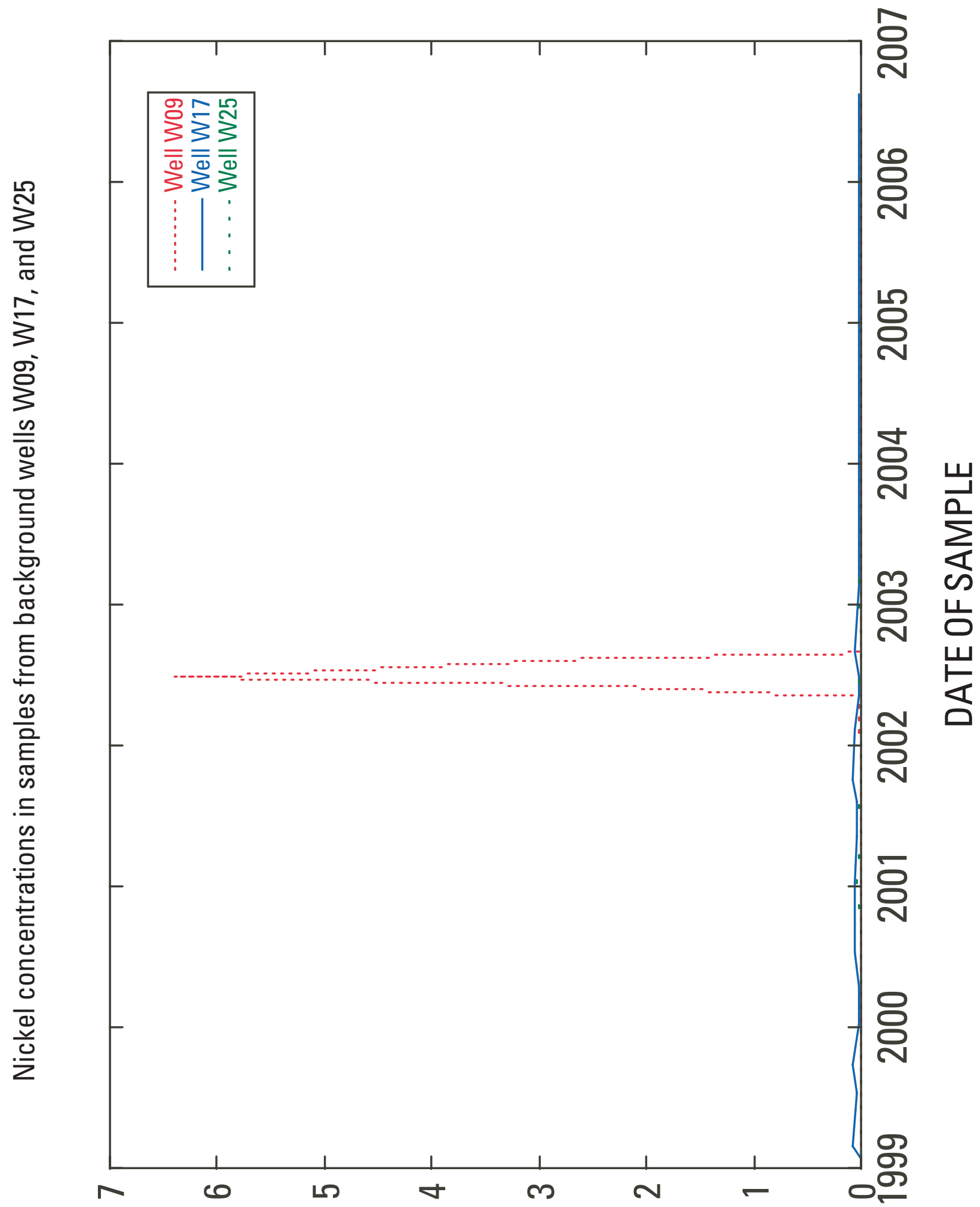

y

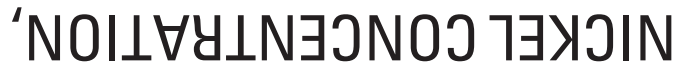




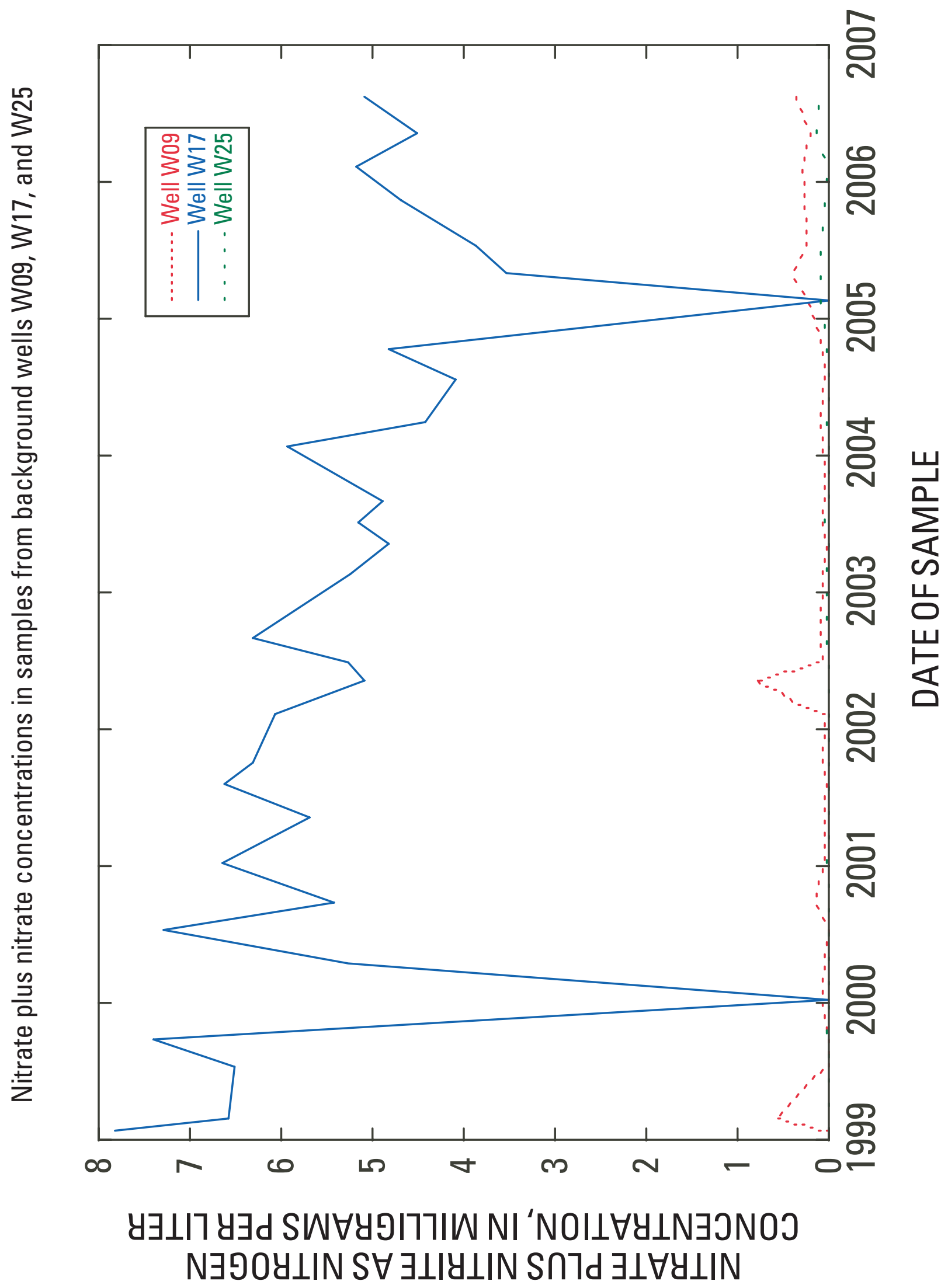




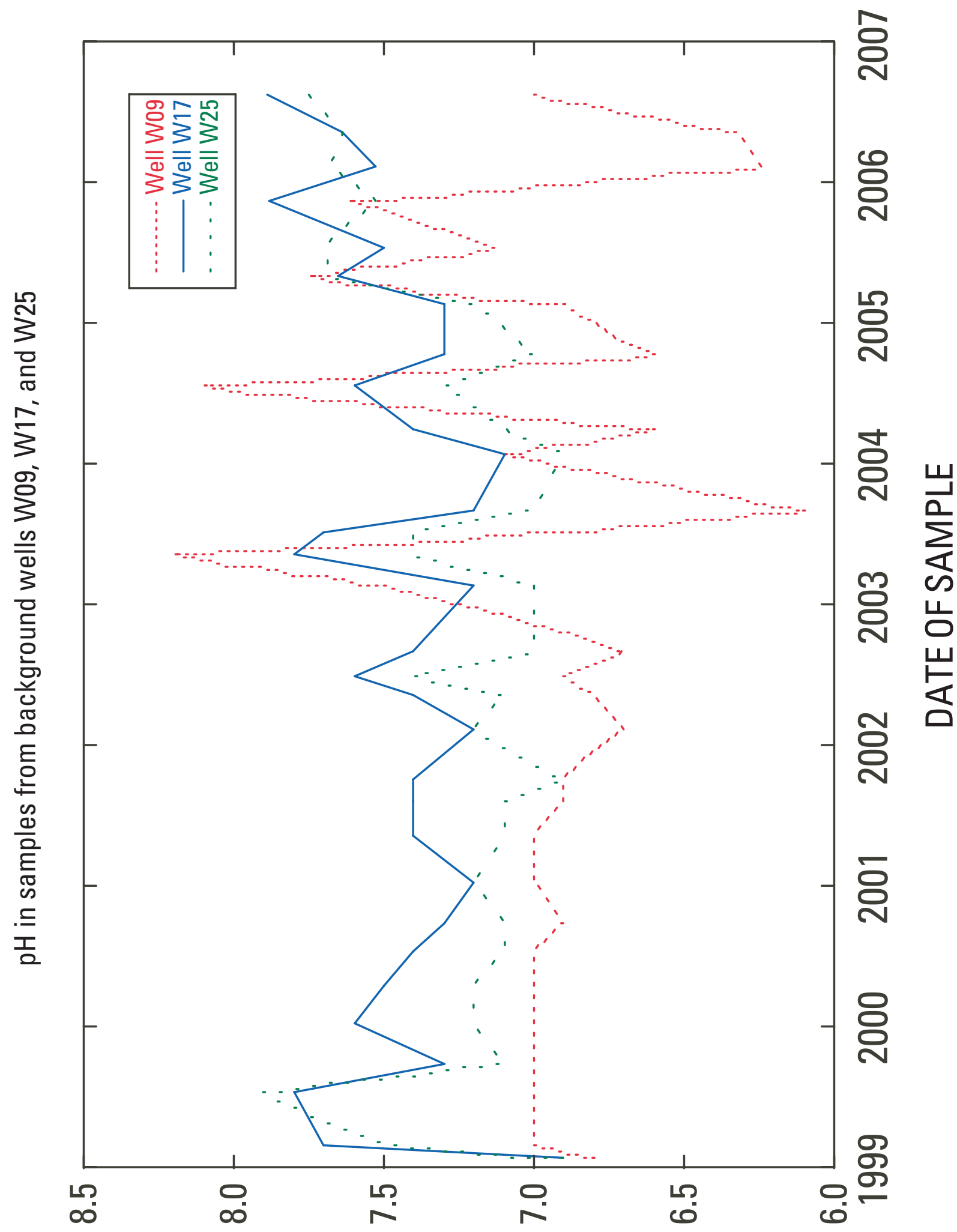

SIINก OYVON $\forall \perp S$ NI 'Hd 


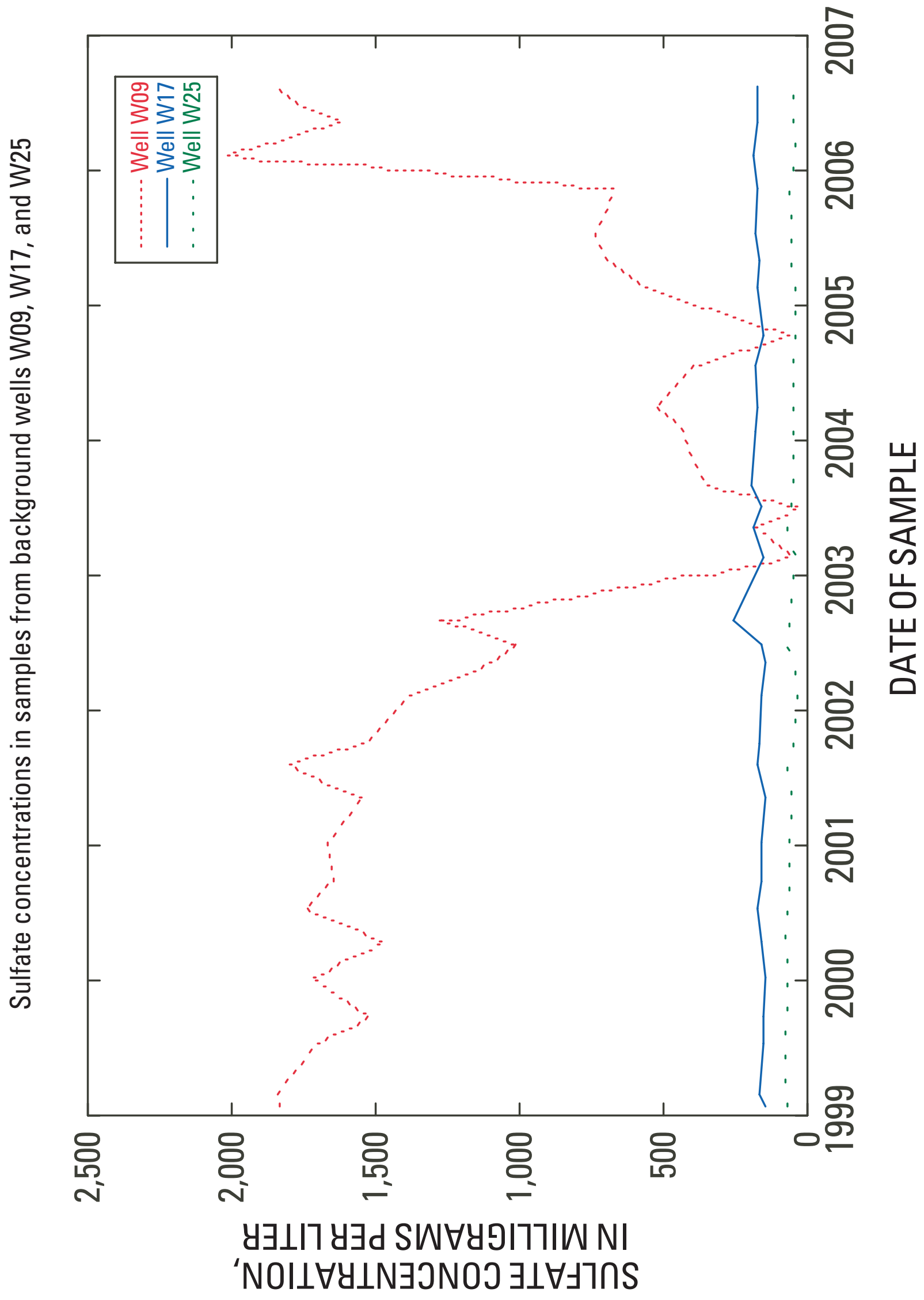




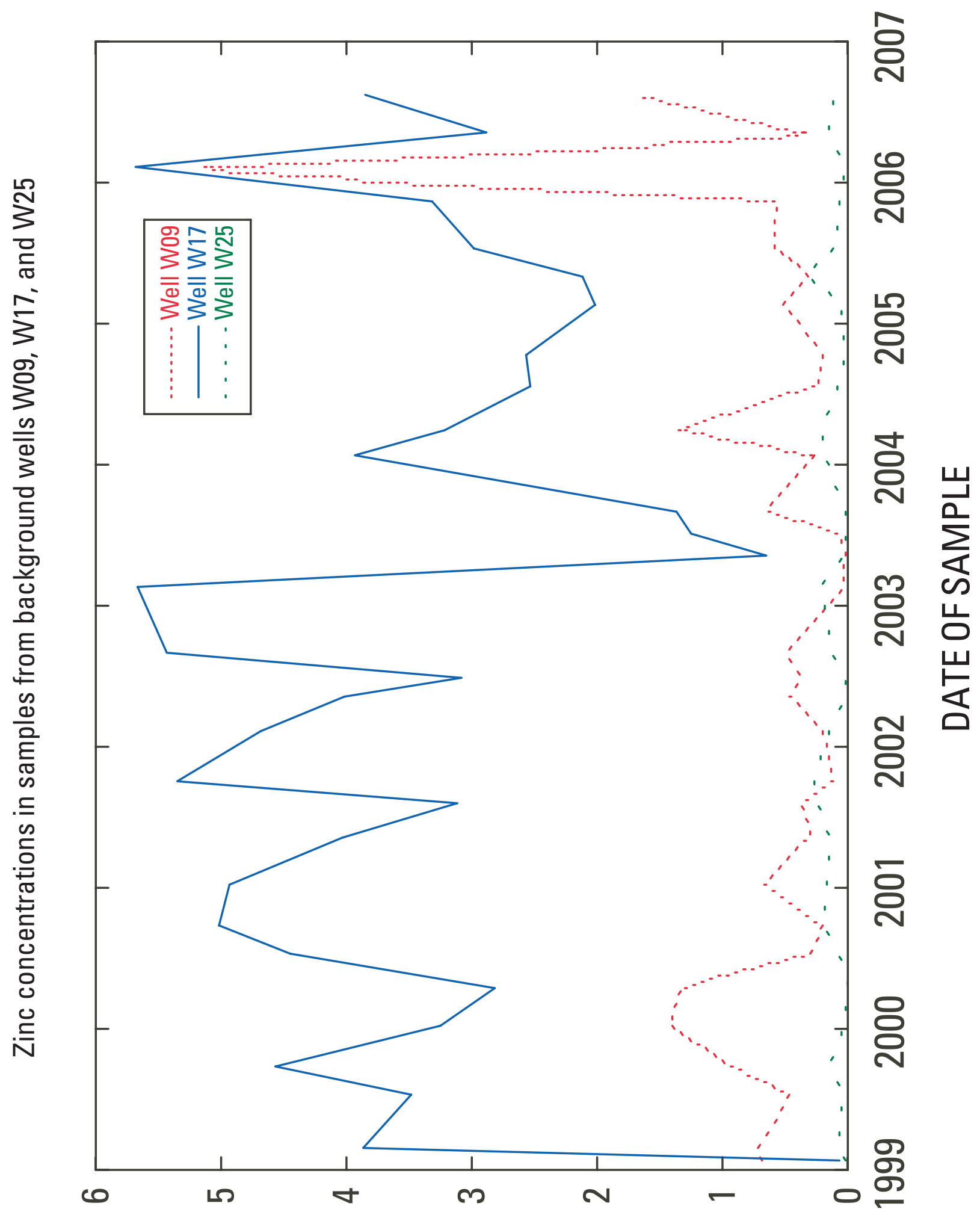

y 17 y

‘NOII $\forall Y \perp N \exists J N O J$ JNIZ 


\section{Prepared by:}

USGS Enterprise Publishing Network

Rolla Publishing Service Center

1400 Independence Road

Rolla, MO 65401

For more information concerning this publication, contact:

Director

U.S. Geological Survey

Illinois Water Science Center

1201 West University Avenue, Suite 100

Urbana, IL 61801-2347

(217) 344-0037

Or visit the Illinois Water Science Center website at: http://il.water.usgs.gov 
Printed on recycled paper 